\title{
MARKOWITZ PORTFOLIO REBALANCING WITH TURNOVER MONITORING
}

\author{
Mikica Drenovak*, Vladimir Rankovic \\ Faculty of Economics, University of Kragujevac, Kragujevac, Serbia
}

\begin{abstract}
Active portfolio management implies periodic rebalancing, i.e. a change in the structure of the existing portfolio. Rebalancing is aimed at improving the performance of the managed portfolio by adjusting it with respect to the given objective. The main objective of this research is to test two portfolio rebalancing strategies, one based on market risk and another on optimal risk-return tradeoff. We use optimal volatility or Sharpe of portfolio as a criterion for the initial portfolio allocation and rebalancing over the observed period. In order to obtain solutions that can be applied in practice, we impose rebalance triggers designed to control the portfolio turnover and corresponding transaction costs. the results suggest that the minimum volatility strategy can be accepted as an eligible investment alternative for risk adverse investors since it provides superior risk performance compared to the reference S\&P 100 index and $1 / n$ portfolio, with a relatively low level of turnover and a low rebalance frequency.
\end{abstract}

Keywords: portfolio management, volatility, Sharpe ratio, portfolio rebalancing, turnover

JEL Classification: C44, C61, G11

\section{INTRODUCTION}

Portfolio management starts with asset allocation. There is a consensus that asset allocation plays an important role in determining portfolio performance (Arshanapalli, Coggin \& Nelson, 2001). Active portfolio management implies the rebalancing of the existing portfolio by buying and selling assets. The aim of rebalancing is to improve the performance of the managed portfolio by adjusting it to the current

\footnotetext{
* Correspondence to: M. Drenovak, Faculty of Economics, University of Kragujevac, Dj. Pucara 3, 34000 Kragujevac, Serbia; e-mail: mdrenovak@kg.ac.rs
}

market conditions. However, portfolio rebalancing induces transaction costs which impact the overall portfolio return. Therefore, transaction costs must be considered when the aim is to develop dynamic portfolio models that perform satisfactorily under the real market conditions (Choi, Jang \& Koo, 2007; Kozhan \& Schmid, 2009).

For decades, market risk has typically been defined as a variance of portfolio returns. Traditionally, portfolio allocation is based upon H. M. Markowitz's meanvariance setup (Markowitz, 1952; Fabozzi, Focardi \& Jonas, 2007). In this paper, we follow Markowitz's setup in choosing portfolio rebalancing strategies. 
Two different strategies are analyzed: 1) the periodic minimization of portfolio risk measured by volatility and 2) the periodic maximization of the portfolio $\mathrm{W}$. F. Sharpe ratio (1966). The aim of the research is to test two rebalancing alternatives: the first one being based on market risk and the other one on the optimal riskreturn tradeoff.

Portfolio allocation is always about a tradeoff between two opposing objectives - risk minimization and return maximization. Market risk (Alexander, 2008) is a risk resulting from adverse movements in the prices of liquid financial instruments. As long as regulators are concerned about the risk profiles of the portfolios under their consideration (Jaksic, 2012), investors seek return and only consider risk in relation to return (either realized or expected). As a rule, portfolio managers report on portfolio performance in terms of realized return per unit of risk taken in the observed period. The Sharpe ratio is the standard in reporting portfolio performance, such ratio being defined as return per unit of the standard deviation (Bacon, 2008).

Whether the periodic optimization of portfolio volatility (or, alternatively, the optimization of the Sharpe ratio) based on the past performance of constituent assets can result in a better-performing portfolio relative to chosen benchmarks is examined. Hence, two hypotheses are tested:

H1: The minimum volatility strategy results in a portfolio with better risk performances compared to chosen benchmarks.

H2: The maximum Sharpe strategy results in a portfolio with a higher Sharpe ratio compared to chosen benchmarks.

In order to control the turnover of the managed portfolios, different rebalancing triggers are introduced. For the purpose of this research, the opportunity set of securities composed of 40 constituents of the U. S. market index S\&P 100 during the rebalancing period of two years are exploited. The risk-return and turnover performance of the managed portfolios to the performance of the S\&P 100 index, adopted as the market benchmark ${ }^{1}$, and the $1 / n$ portfolio, adopted as a naive portfolio strategy benchmark are compared.
Different investment objectives determine the rebalancing strategies to be applied (Hsu, 2012). B. Arshanapalli et al. (2001) examine the impact of asset allocation on the performance of the fixed-weight and different dynamic portfolios with and without a transaction costs assumption. C. Donohue and K. Yip (2003) examine the implied portfolio performance, the result of common heuristic rebalancing strategies, in terms of risk, return, the Sharpe ratio, turnover and transaction costs. The results intuitively suggest that there is a tradeoff between the optimal rebalancing and transaction costs's. K. Sippel (2013) analyzes the impact of the portfolio turnover on the performance of the specific strategy indices designed to target the required level of portfolio risk. The author introduces transaction buffers with the aim to decrease turnover and improve the cost-adjusted performance of the managed portfolio. V. DeMiguel, G. Lorenzo and U. Raman (2009) evaluate the out-of-sample performance of the portfolios with the optimal asset allocation, using Markowitz's model and its extensions (14 different models in total). The authors demonstrate that the naïve $1 / n$ optimization rule generates a good proxy of the optimal portfolio that can be confronted with more complex portfolio designs. A. A. Gaivoronsky, S. Krylov and N. Van der Wijst (2005) analyze the portfolio selection approach when portfolio performance is defined relatively to the given benchmark (the benchmark tracking approach). The authors have developed several portfolio selection algorithms based on different risk measures, and they have tested them through a number of numerical experiments. The results show that their approach, based on benchmark tracking, can be an attractive investment strategy. In their study, J. R. Yu and W. Y. Lee (2011) analyze five different portfolio rebalancing models based on the combination of different rebalancing criteria, including risk, return, the short selling constraint and the skewness and kurtosis of return distribution, taking the transaction cost into consideration.

Upon the outbreak of the subprime crisis, investors and regulators became increasingly concerned about the risk of extreme quantiles. The risk of extreme quantiles is defined with the aim to estimate the impact of unfavorable and highly improbable events. Despite its unfavorable mathematical properties (Artzner, 
Delbaen, Eber \& Heath, 1999; Szego, 2002), VaR is the predominantly used risk measure of extreme quantiles, in particular upon the introduction of the new banking regulations in 1996 (Basel Committee on Banking Supervision, 19963). By t regulation, a bank's internal VaR estimates are incorporated into a capital charge which aims to provide a sufficient buffer for cumulative losses arising from adverse market conditions. For this reason, the VaR values of the examined portfolios will be calculated and presented here.

The remainder of this paper is organized as follows: in Section 2, the concepts of portfolio return and turnover are introduced. The risk and risk-adjusted measures that we base our rebalancing upon are introduced in Section 3. The optimization model is introduced in Section 4. In Section 5, the proposed rebalancing strategies are presented. Section 6 provides the empirical results. Our conclusions and suggestions for future research are given in Section 7.

\section{THE MATHEMATICS OF PORTFOLIO RETURN AND TURNOVER}

In this section, the basic relationships of the portfolio theory exploited in this research are introduced.

Percentage one-period return of the portfolio at time $t$ is defined as:

$r_{p, t}=\sum_{i=1}^{N} w_{i, t-1} r_{i, t}$

where $r_{i, t}$ denotes the percentage one-period return of asset $i$ at time $t$, and $w_{i, t}$ denotes the proportion of the capital invested in asset $i$ at time $t$.

Expression (1) is the fundamental relationship in portfolio mathematics (Alexander, 2008).

Weighting factor $w_{i, t}$ is defined as:

$w_{i, t}=\frac{n_{i} p_{i, t}}{\sum_{i=1}^{N} n_{i} p_{i, t}}, \quad i=1, \ldots, N$,

where $n_{i}$ is the number of the shares of asset $i$ and $p_{i, t}$ is the price per share of asset $i$ at time $t$.
The number of shares $n_{i}$ remains the same for each asset $i$ for the period between the two rebalances (i.e. the portfolio remains static). On the other hand, the proportion of the capital invested in each asset $w_{i, t}$ changes over time, whenever the price of any asset in such portfolio changes.

Transaction (trading) costs, as a consequence of rebalancing, may have a great impact on the overall portfolio return. In practice, a portfolio manager must control the level of transaction costs in order not to ruin the overall portfolio performance. As a result, transaction costs are always considered as an important constraint in portfolio management. Transaction costs depend on multiple factors and follow different patterns; however, as a rule, they are directly affected by portfolio turnover (a trading volume). In this research, we restrain ourselves from going deeper into those different patterns. Due to simplicity, portfolio turnover as a proxy for transaction costs is used. Portfolio turnover at time $t$, expressed as the percentage of the portfolio value, is calculated using the following formula (DeMiguel et al, 2009):

Turnover $(t)=\sum_{i=1}^{N}\left|w_{i, t}-w_{i, t-1}\right|$

RISK AND RISK-ADJUSTED MEASURES USED AS THE OPTIMIZATION CRITERION

\section{Volatility}

Portfolio variability is commonly calculated as the variance of portfolio returns:

$\sigma_{p}^{2}=\frac{1}{T} \sum_{t=1}^{T}\left(r_{t}-\bar{r}_{p}\right)^{2}$, where $r_{i}$ is portfolio return at time $t, \bar{r}_{p}$ is the average portfolio return. Often, investors use the standard deviation $\sigma_{p}$, i.e. the squared root of the variance, as the measure of portfolio variability, given that the standard deviation is of the same order as the average return. The benchmark measure of portfolio variability is volatility, calculated as the annualized standard deviation of portfolio returns $s^{4}$ : 
volatility $=\sigma_{p} \sqrt{252}$

\section{Sharpe ratio}

The Sharpe ratio ${ }^{5}$ measures portfolio return as per the unit of risk. It is one of the most frequently used measures of the risk-adjusted portfolio performance and quantifies the risk-return tradeoff. The return is commonly calculated relative to the given riskfree rate, while risk is measured using the standard deviation of portfolio returns. Of the two portfolios with the same return, a higher Sharpe ratio will favor the portfolio with less variability in returns, measured by the standard deviation. The Sharpe ratio is suitable for evaluating portfolios with different returns and different levels of risk for the same period. Formally, it is defined as:

Sharpe $=\frac{\bar{r}_{p}-r_{f}}{\sigma_{p}}$,

where $\bar{r}_{p}$ is the average portfolio return, $r_{f}$ is the riskfree rate and $\sigma_{p}$ is the standard deviation of portfolio returns.

\section{OPTIMIZATION MODEL}

This research analyzes two different portfolio rebalancing strategies based on: a) the minimization of portfolio volatility and b) the maximization of the portfolio Sharpe ratio. The general form of the optimization model is defined as follows:

a) min volatility $\left(r_{p}(\boldsymbol{w})\right)$

b) max Sharpe $\left(r_{p}(\boldsymbol{w})\right)$

$\sum_{i=1}^{N} w_{i}=1$

$0 \leqslant w_{i} \leqslant 1, i=1, \ldots, N$,

where $w$ denotes the vector of weighting factors $w_{i}$ volatility $(r p(w))$ denotes the volatility of a portfolio, Sharpe(rp $(w))$ denotes the Sharpe ratio and $N$ is the total number of assets.
Equation (6) defines the optimization models; Equation (7) describes the standard budget constraint requiring that weighting factors must sum up to 1; Equation. (8) describes the constraint that no short sales are allowed, implying that none of the weighting factors can be negative.

We emphasize that the optimization criterion (volatility or the Sharpe ratio estimate) of the portfolio is calculated using the time series of the realized portfolio returns (we fix portfolio holdings). To calculate the time series of the realized returns of the candidate portfolio, the daily recalculations of its weighting factors $w_{i, t}$ are needed.

\section{REBALANCING STRATEGIES}

The proposed rebalancing strategies are based on the daily portfolio optimization with respect to the chosen criterion (Equation (6)).

On the first day of the sample period, as the initial portfolio, we chose the optimized portfolio (in terms of: (a) minimal volatility, b) the maximal Sharpe ratio). The initial portfolio is defined by the set of weighting factors $w_{i}$. These weighting factors are transformed into portfolio holdings, assuming that the initial portfolio value is equal to $\$ 1$ million.

For each next day within the observed rebalancing period, the portfolio optimization procedure is applied. If the stated minimal improvement of the optimization criterion is achieved and if the rebalancing condition (the trigger) is satisfied, the rebalance is performed so that the optimized portfolio becomes the actual portfolio to be managed in the future. Otherwise, the existing portfolio remains unchanged. Here, we set the minimal improvement condition to be $1 \%$.

\section{DATA AND RESEARCH RESULTS}

In this section, the computational results obtained by applying the proposed strategies to the historical data set are displayed. For the purpose of this research, the 40 constituents of the S\&P 100 index (based on: the historical prices of the S\&P 100 index and its 
constituents) with the highest market capitalization as of September 6 ${ }^{\text {th }}, 2013$ are exploited ${ }^{6}$.

Rebalancing was performed within the period of two years (504 trading days), starting on January $2^{\text {nd }}, 2009$ and ending on December $31^{\text {st }}, 2010$. For volatility and the Sharpe estimation, 500 daily return observations were used.

In order to evaluate the performance of the proposed portfolio strategies, the performance of the managed portfolios are compared to the performance of the $1 / n$ portfolio and the reference S\&P 100 index.

Figure 1 shows the market value of the portfolios managed by applying minimal volatility (Min Volatility), the maximal Sharpe ratio (Max Sharpe) and the $1 / n$ portfolio strategy together with the normalized level of the S\&P100 index.

Pursuant to the Basel regulations framework, the 1-day ahead of $1 \%$ VaR estimate will be reflected in the level of the capital requirements for financial institutions. Figure 2 shows the evolution of the historical 1\%
VaR estimates over the rebalancing period for Min Volatility, Max Sharpe and the 1/n portfolios and the S\&P100 index.

Table 1 accounts for the performance statistics for the managed portfolios.

As expected, the Min Volatility strategy provides the lowest volatility, and in addition, the lowest $1 \%$ $\mathrm{VaR}$ estimates over the rebalancing period. The Max Sharpe strategy results in the highest estimated Sharpe ratio accompanied by the highest volatility over the observed period. The high volatility of the Max Sharpe portfolio is the result of the extreme changes in the portfolio structure (see Table 1 for the total turnover statistics). The time series of the $\mathrm{VaR}$ estimates reveal the significant changes in the VaR level for the Max Sharpe portfolio as the result of the radical changes of the portfolio structure.

The results accounted for in Table 1 show that the Max Sharpe strategy provides a maximum return (the total and average daily return) and the maximum Sharpe

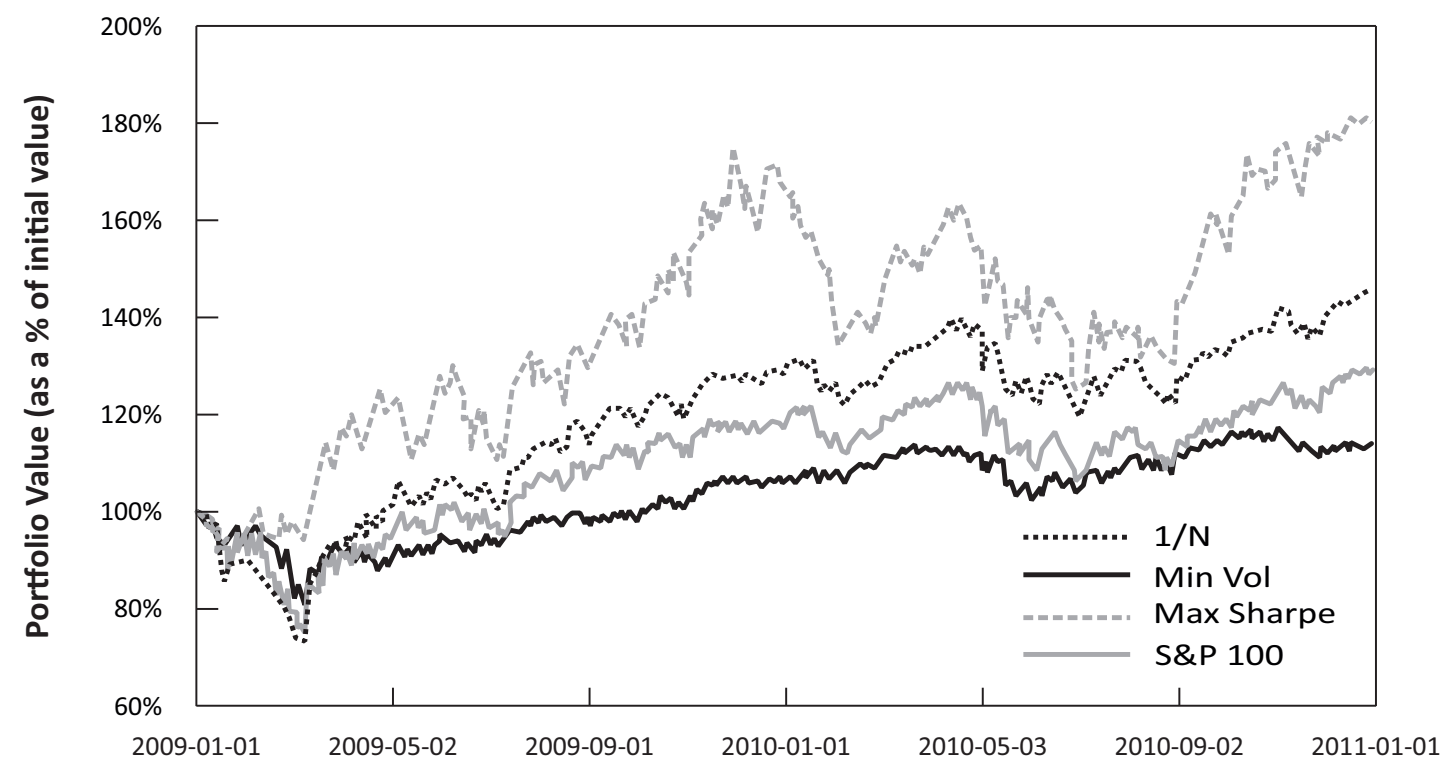

Figure 1 The market value of the managed portfolios obtained by using the Min Volatility and Max Sharpe rebalancing strategies, the 1/n portfolio strategy and of the benchmark S\&P 100 index for the period from January $2^{\text {nd }}, 2009$ to December $31^{\text {st }}, 2010$ 


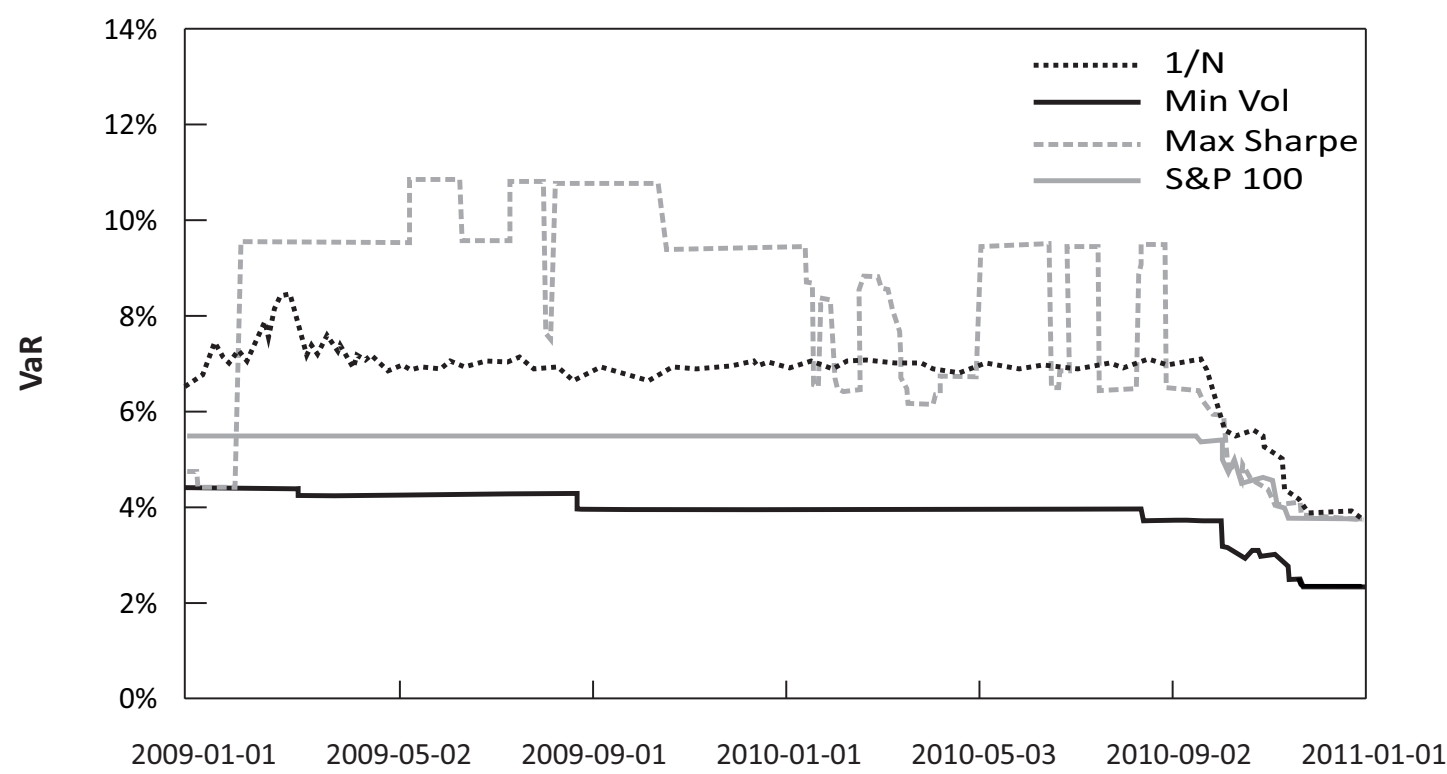

Figure 2 The time series of the 1\%VaR estimates of the managed portfolios obtained by using the Min Volatility and Max Sharpe rebalancing strategies, the 1/n portfolio strategy, and of the benchmark S\&P 100 index for the period from January $2^{\text {nd }}, 2009$ to December $31^{\text {st }}, 2010$

Source: Authors

Table 1 The performance statistics of the managed portfolios obtained by applying the Min Volatility and Max Sharpe rebalancing strategies, the 1/n portfolio strategy, and of the benchmark S\&P 100 index for the period from January $2^{\text {nd }}, 2009$ to December $31^{\text {st }}, 2010$

\begin{tabular}{l|cccc}
\hline & Min Volatility & Max Sharpe & $1 / \mathrm{N}$ & S\&P 100 \\
\hline Total return & $11.18 \%$ & $79.12 \%$ & $43.68 \%$ & $27.31 \%$ \\
Total turnover & $204.06 \%$ & $3658.67 \%$ & $569.25 \%$ & - \\
No. of rebalances & 7 & 46 & 504 & - \\
Avg. return (ann.*) & $6.31 \%$ & $34.48 \%$ & $21.11 \%$ & $14.45 \%$ \\
Volatility & $14.18 \%$ & $32.56 \%$ & $24.35 \%$ & $21.70 \%$ \\
1\%VaR & $2.77 \%$ & $4.65 \%$ & $4.62 \%$ & $4.05 \%$ \\
Max drawdown** & $-8.03 \%$ & $-8.97 \%$ & $-8.56 \%$ & $-7.84 \%$ \\
Sharpe*** & 0.42 & 1.05 & 0.86 & 0.65 \\
Avg. no. of assets & 7.2 & 1.6 & 40 & 100 \\
\hline
\end{tabular}

*annualized

** The max drawdown is calculated as a maximum 3-day loss with the assumption that a 3-day horizon is the period long enough for closing the position in liquid markets.

*** The Sharpe ratio is calculated by applying the 1-year U.S. Treasury rate of $0.29 \%$ as of December $31^{\text {st }}, 2010$ as the risk-free rate. (The U.S. Department of Treasury)

Source: Authors 
ratio at the expense of a very high turnover (over 36 average portfolio values). On the other hand, the Min Volatility strategy provides the lowest volatility and the $1 \% \mathrm{VaR}$ at the expense of the lowest return. If compared to the performance of the benchmark S\&P 100 index, the Min Volatility strategy provides a lower return as well as a significantly lower volatility and the $1 \% \mathrm{VaR}$ (the same applies if compared to the $1 / \mathrm{n}$ strategy). Additionally, the VaR estimates over the observed period are the lowest for the Min Volatility portfolio and the highest for the Max Sharpe portfolio which implies a more (less) efficient use of regulatory capital. The naïve $1 / n$ strategy delivers performance in between the Min Volatility and the Max Sharpe strategies, which is expected for the fixed-weightingfactor portfolio strategy (Arshanapalli et al, 2001).

It is emphasized that, as long as the rebalance frequency of the Max Sharpe strategy is acceptable in practical terms, the turnover values of individual rebalances are high in most occurrences. On the other hand, the $1 / n$ strategy implies daily rebalancing. Consequently, each of these three strategies results in a very high total turnover, which implies transaction costs impossible to sustain under real market conditions.

In order to decrease the total turnover, the following turnover constraints are imposed:

For the Min Volatility and the Max Sharpe strategy, rebalancing is only performed if turnover is less than $50 \%$ of the total portfolio value (the sum of the total selling and the total buying), whereas in the case of the $1 / \mathrm{n}$ strategy, rebalance is only realized if turnover is greater than $5 \%$ of the portfolio value. Otherwise, the existing portfolio remains.

Figure 3 shows the market value of the portfolios managed by applying the Min Volatility, Max Sharpe and $1 / \mathrm{n}$ portfolio strategies with turnover constraints imposed, while Figure 4 shows the evolution of the $\mathrm{VaR}$ estimates over the rebalancing period for the same portfolios.

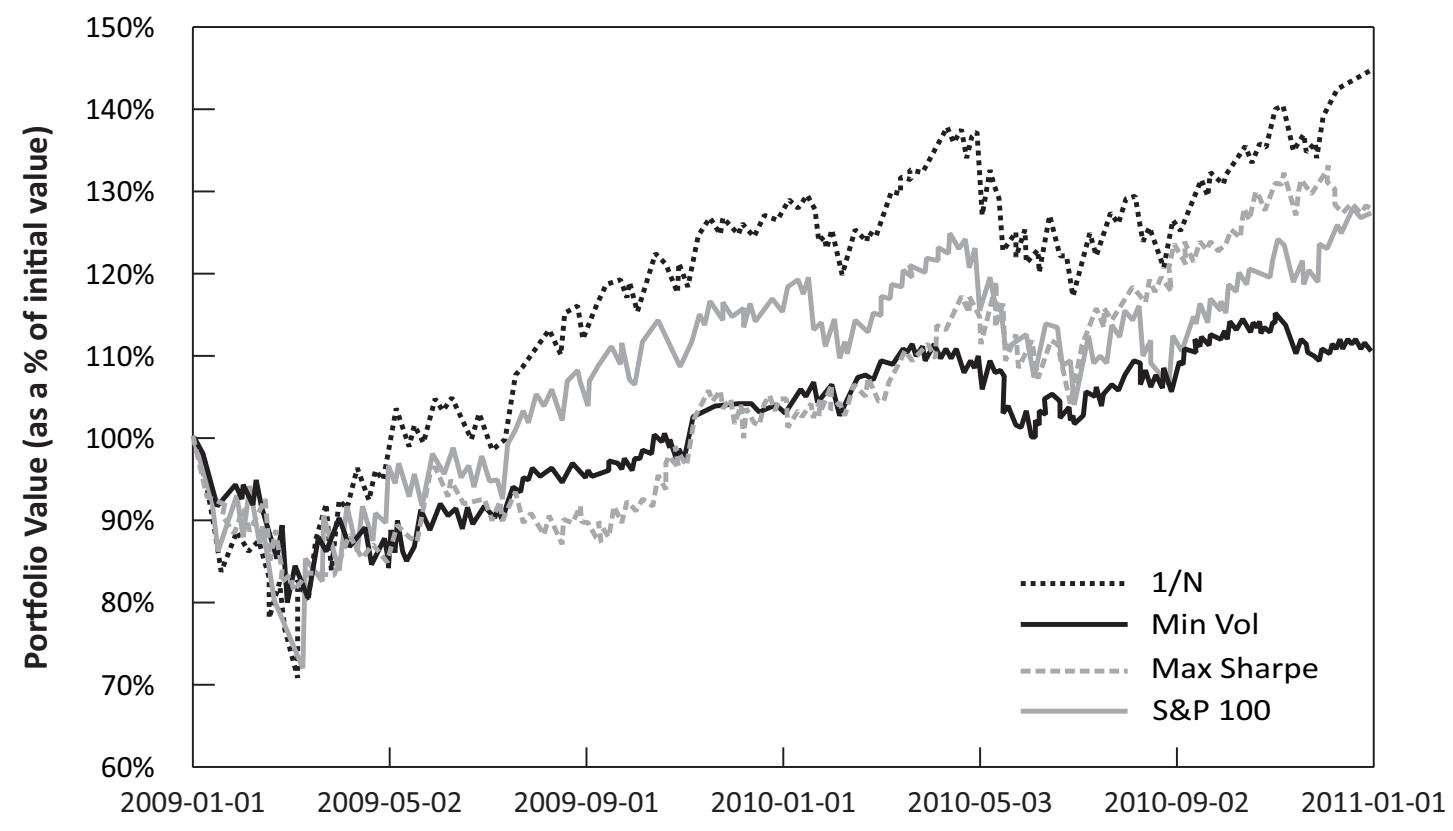

Figure 3 The market value of the managed portfolios obtained by using the Min Volatility and the Max Sharpe rebalancing strategies, with the maximum turnover constraint, the $1 / \mathrm{n}$ portfolio strategy with the minimum turnover constraint and of the benchmark S\&P 100 index for the period from January $2^{\text {nd }}, 2009$ to December $31^{\text {st }}, 2010$ 


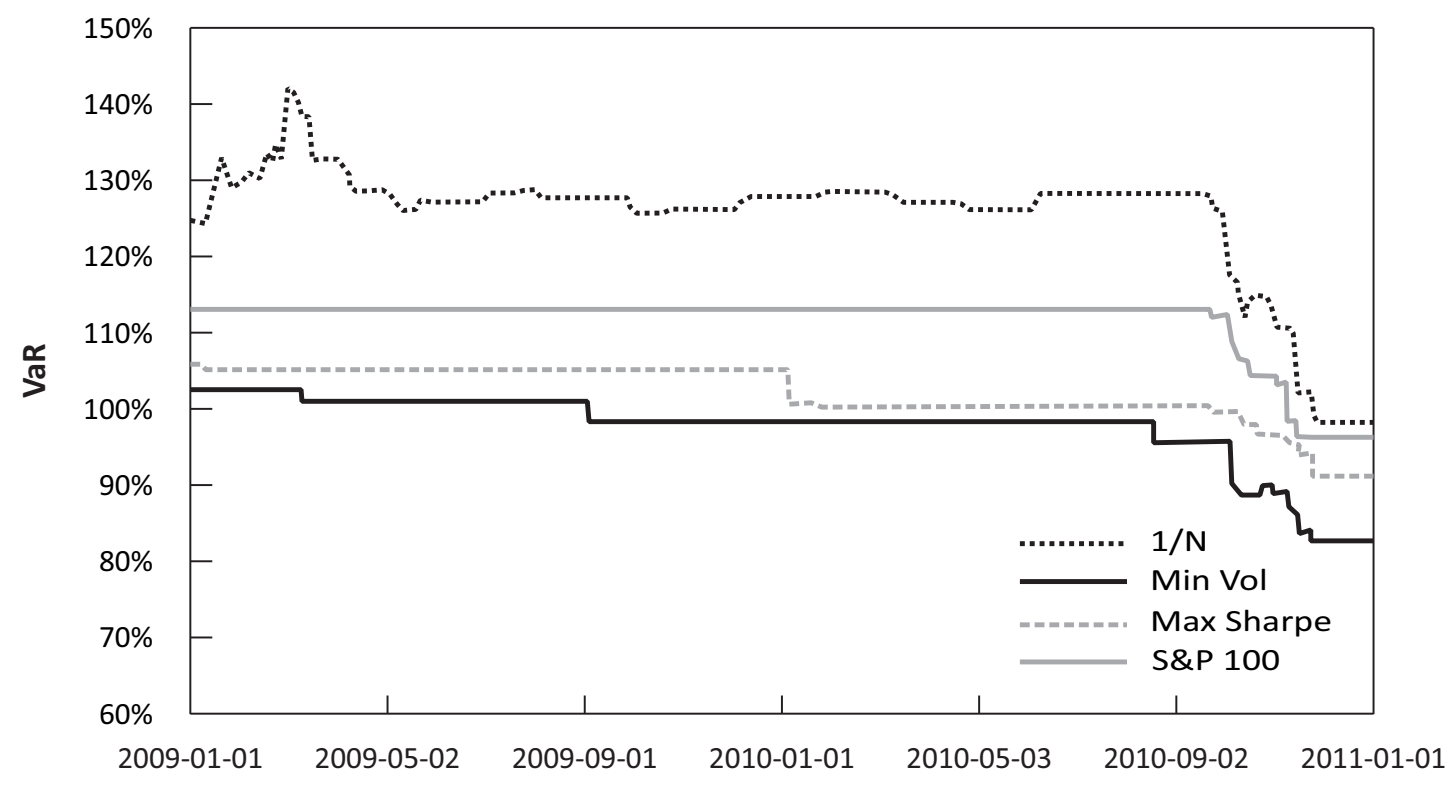

Figure 4 The 1\%VaR estimates of the managed portfolios obtained by applying the Min Volatility and the Max Sharpe rebalancing strategies with the maximum turnover constraint, the 1/n portfolio strategy with the minimum turnover constraint and of the benchmark S\&P 100 index for the period from January $2^{\text {nd }}, 2009$ to December $31^{\text {st }}, 2010$

Source: Authors

In Table 2, we present the performance statistics for the managed portfolios with the turnover constraints imposed.

After imposing the turnover constraints, the Min Volatility portfolio remains the same. On the other hand, the total turnover of the Max Sharpe strategy decreases to $13.73 \%$, with only three realized rebalances with a decrease of more than $50 \%$ in the total return compared to the unconstrained version of the strategy. Furthermore, the Sharpe ratio is no longer the highest in the sample (but the VaR estimates are significantly lower).

Then again, the Min Volatility strategy delivers the lowest standard deviation and the $1 \% \mathrm{VaR}$.

Imposing the turnover constraint to the $1 / n$ strategy results in the significantly lower total turnover $(158.48 \%$ vs. $569.25 \%$ ) within 29 instead of 504 rebalances, while the balanced overall performance still remains.

The aim of portfolio allocation is to induce diversification effects, i.e. to exclude the idiosyncratic risk of individual assets and deliver more balanced risk/return characteristics. Portfolio theory suggests that the more assets included the greater is the diversification effect (Markowitz, 1952). In practice, investors try to achieve maximum diversification effects with the minimum portfolio cardinality, thus avoiding high management costs. The presented strategies are applied to the opportunity set of 40 assets ${ }^{7}$. Including no more than two assets on average, the Max Sharpe strategy provides poor diversification effects, regardless of whether the turnover constraint is imposed or not. Simultaneously, the Min Volatility strategy delivers superior effects on risk values (volatility and $\mathrm{VaR}$ ) relative to the $1 / \mathrm{n}$ strategy and the benchmark S\&P 100 index, including only 7 assets on average, but at the expense of a modest return.In order to check the robustness of our results with respect to the observed period, the same tests for the new period of two years (504 trading days), starting on September $1^{\text {st }}, 2011$ and ending on September $4^{\text {th }}, 2013$ have been performed (S\&P 100 index, https://finance.yahoo. 
Table 2 The performance statistics of the managed portfolios obtained by applying the Min Volatility and the Max Sharpe rebalancing strategies with the maximum turnover constraint, the $1 / n$ portfolio strategy with the minimum turnover constraint and of the benchmark S\&P 100 index for the period from January $2^{\text {nd }}, 2009$ to December $31^{\text {st }}, 2010$

\begin{tabular}{l|cccc}
\hline & $\begin{array}{c}\text { Min Volatility } \\
\text { turnover <50\% }\end{array}$ & $\begin{array}{c}\text { Max Sharpe } \\
\text { turnover <50\% }\end{array}$ & $\begin{array}{c}1 / \mathrm{N} \\
\text { turnover }>5 \%\end{array}$ & S\&P 100 \\
\hline Total return & $11.18 \%$ & $27.72 \%$ & $43.76 \%$ & $27.31 \%$ \\
Total turnover & $204.06 \%$ & $13.73 \%$ & $158.48 \%$ & - \\
No. of rebalances & 7 & 3 & 29 & - \\
Avg. return (ann.) & $6.31 \%$ & $14.08 \%$ & $21.14 \%$ & $14.45 \%$ \\
StdDev (ann.) & $14.18 \%$ & $19.09 \%$ & $24.36 \%$ & $21.70 \%$ \\
VaR1\% & $2.77 \%$ & $3.05 \%$ & $4.45 \%$ & $4.05 \%$ \\
Max drawdown & $-8.03 \%$ & $-4.89 \%$ & $-8.23 \%$ & $-7.84 \%$ \\
Sharpe & 0.42 & 0.72 & 0.86 & 0.65 \\
Avg. no. of assets & 7.2 & 2.0 & 40 & 100 \\
\hline
\end{tabular}

Source: Authors

com). For the purpose of brevity, we only present the performance statistics of the portfolios obtained by applying the Min Volatility and the Max Sharpe rebalancing strategies with the maximum turnover constraint in Table 3. The results are consistent with those obtained for the 2009-2010 period (except for the fact that, this time, the Max Sharpe strategy has resulted in a higher number of rebalances and a higher turnover). For the reasons of comparability, the same Treasury rate of $0.29 \%$ as in the previous tests is used.

Table 3 The performance statistics of the managed portfolios obtained by applying the Min Volatility and the Max Sharpe rebalancing strategies with the maximum turnover constraint, the $1 / \mathrm{n}$ portfolio strategy with the minimum turnover constraint and of the benchmark S\&P 100 index for the period from September $1^{\text {st }}, 2011$ to September $4^{\text {th }}$, 2013

\begin{tabular}{|c|c|c|c|c|}
\hline & $\begin{array}{c}\text { Min Volatility } \\
\text { turnover }<50 \%\end{array}$ & $\begin{array}{c}\text { Max Sharpe } \\
\text { turnover }<50 \%\end{array}$ & $\begin{array}{c}1 / \mathrm{N} \\
\text { turnover }>5 \%\end{array}$ & S\&P 100 \\
\hline Total return & $23.54 \%$ & $35.05 \%$ & $43.92 \%$ & $36.33 \%$ \\
\hline Total turnover & $82.15 \%$ & $273.03 \%$ & $67.19 \%$ & \\
\hline No. of rebalances & 5 & 9 & 14 & \\
\hline Avg. return (ann.) & $11.14 \%$ & $16.15 \%$ & $19.39 \%$ & $16.69 \%$ \\
\hline StdDev (ann.) & $10.45 \%$ & $14.82 \%$ & $15.15 \%$ & $15.24 \%$ \\
\hline $1 \%$ VaR1 & $1.87 \%$ & $2.37 \%$ & $2.60 \%$ & $2.59 \%$ \\
\hline Max drawdown & $-3.70 \%$ & $-4.89 \%$ & $-8.23 \%$ & $-5.89 \%$ \\
\hline Sharpe & 1.04 & 1.07 & 1.26 & 1.07 \\
\hline Avg. no. of assets & 5.4 & 3.4 & 40 & 100 \\
\hline
\end{tabular}

Source: Authors 


\section{CONCLUSION}

This paper presents two alternative portfolio management strategies: the first one is based on the minimization of volatility and the other one is based on the maximization of the Sharpe ratio. The resulting performance is compared to the benchmark, the $1 / n$ portfolio strategy and the reference S\&P 100 index.

Consistent to Hypothesis H1, the Min Volatility strategy delivers a portfolio with the minimum risk (in terms of volatility and $1 \% \mathrm{VaR}$ ). The Max Sharpe strategy delivers a portfolio with the maximum return (on an absolute and risk-adjusted basis, expressed by the Sharpe ratio) consistent to Hypothesis H2. Although theoretically appealing, the Max Sharpe solution portfolio is not feasible under real market conditions due to a very high total turnover ${ }^{8}$. In order to control the portfolio turnover, turnover constraints have been introduced.

It has turned out that imposing a turnover constraint on the Sharpe strategy in a way it is proposed here is not eligible since it induces a portfolio solution with very poor performances. However, the Min Volatility strategy still provides a superior risk performance in comparison with the reference S\&P 100 index and the $1 / n$ portfolio with a relatively low level of turnover and a low rebalance frequency. Therefore, this is an acceptable investment alternative to market capitalization and the equal-weighting-factor-based approach for risk adverse investors.

There is an empty room for future research into the impact of different transaction cost patterns on chosen rebalancing criteria. How a different length of historical data impacts the final solution should also be explored. There are two extreme rebalancing scenarios that have been applied in this paper: the one with no turnover constraint and the other with constraints imposed in a way that any turnover exceedance prevents the execution of a rebalance. It would be worthwhile to expand research into the rebalancing solutions that conform to the predefined daily level of turnover.

\section{ACKNOWLEDGEMENTS}

The research presented in this paper was supported by the Ministry of Education, Science and Technological Development of the Republic of Serbia, No. OH 179005 and No. III 44010.

\section{ENDNOTES}

1 Nowadays, market indexes are easily investable through exposure to exchange-traded funds. See, for example, the factsheet for the ishares S\&P 100 ETF (Ticker: OEF).

2 The optimal rebalancing strategy is the one minimizing the expected future transaction costs and the tracking error, defined to be a distance from the current asset ratios to the target ratios.

3 The 1988 Basel Capital Accord created the first riskbased capital adequacy requirement for banks, while the 1996 amendment to the Capital Accord brought some improvements of the original accord regarding market risk.

4 The number 252 stands for the number of trading days per year, while 250 is often alternatively used

5 The Sharpe ratio is initially introduced as a reward to the variability ratio (Sharpe, 1966; Bacon, 2008).

6 The first 40 S\&P 100 constituents with the data available as at Dec. 3 rd, 2007 are included in the sample.

7 These 40 assets (out of the 100 index constituents) comprise more than $70 \%$ of the market capitalization of the underlying S\&P 100 index portfolio.

8 In addition, the unreported results show that the Max Sharpe strategy induces occasional, very large changes in the portfolio composition.

\section{REFERENCES}

Alexander, C. (2008). Quantitative Methods in Finance. London, UK: John Wiley \& Sons Ltd.

Arshanapalli, B., Coggin, T. D., \& Nelson. W. (2001). Is FixedWeight Asset Allocation Really Better? The Journal of Portfolio Management, 27(4), 27-38. doi: 10.3905/jpm.2001.319799

Artzner, P., Delbaen, F., Eber, J. M., \& Heath, D. (1999). Coherent 
measures of risk. Mathematical Finance, 9(3), 203-228. doi: 10.1111/1467-9965.00068

Bacon, C. (2008), Practical portfolio performance measurement and attribution. London, UK: John Wiley \& Sons.

Basel Committee on Banking Supervision, (1996). Amendment to the Capital Accord to Incorporate Market Risks. Bank for International Settlements.

Choi, U. J., Jang, B. G., \& Koo, H. K. (2007). An algorithm for optimal portfolio selection problems with transaction costs and random lifetimes. Applied Mathematics and Computation. 191, 239-252. doi: 10.1016/j.amc.2007.02.100

Donohue, C., \& Yip, K. (2003). Optimal Portfolio Rebalancing with Transaction Costs. Journal of Portfolio Management, 29, 49-63. doi: 10.3905/jpm.2003.319894

DeMiguel, V., Lorenzo, G., \& Raman, U. (2009). Optimal Versus Naive Diversification: How Inefficient is the 1/N Portfolio Strategy? The Review of Financial Studies, 22(5), 1915-1953. doi: 10.1093/rfs/hhm075

Fabozzi F. J., Focardi, S, \& Jonas, C. (2007). Trends in quantitative equity management: Survey results. Quantitative Finance, 7, 115-122. doi: 10.1080/14697680701195941

Factsheet for the iShares S\&P 100 ETF, učitano 8. jula 2014. godine sa http://www.ishares.com/us/library?materialType =Prospectus\&keyword=US4642871010.

Gaivoronski, A. A., Krylov, S., \& Van der Wijst, N. (2005). Optimal portfolio selection and dynamic benchmark tracking. European Journal of Operational Research, 163(1), 115161. doi: 10.1016/j.ejor.2003.12.001
Hsu, J. (2012). Why We Don't Rebalance. Učitano 8. jula 2014. godine sa http://www.etf.com/sections/research/12647-whywe-dont-rebalance.html?showall=\&fullart $=1 \&$ start $=4$

Istorijske cene S\&P 100 indeksa i njegovih konstituenata učitane na dan 8. septembar 2013 https://finance.yahoo.com/

Jaksic, M. (2012). Risk management of portfolio securities. Ekonomic horizons, 14(3), 155-168. doi: 10.5937/ekonhor1203151J

Kozhan, R., \& Schmid, W. (2009). Asset allocation with distorted beliefs and transaction costs. European Journal of Operational Research, 194(1), 236-249. doi: 10.1016/j.ejor.2007.12.002

Markowitz, H. M. (1952). Portfolio selection. Journal of Finance, 7, 77-91. doi: 10.1111/j.1540-6261.1952.tb01525.x

Sharpe, W. F. (1966). Mutual Fund Performance. The Journal of Business, 39(1), 119-138.

Sippel, K. (2012). Trading Costs and Index Design. Journal of Indexes Europe, September/October, 8-13, učitano 8. jula 2014. godine sa http://europe.etf.com/europe/publications/ journal-of-indexes/articles/8467-trading-costs-and-indexdesign.html

Szego, G. (2002). Measures of risk. Journal of Banking \& Finance, 26, 1253-1272. doi: 10.1016/S0378-4266(02)00262-5

U.S. Department of the Treasury, http://www.treasury.gov/ Pages/default.aspx

Yu, J. R., \& Lee, W. Y. (2011). Portfolio rebalancing model using multiple criteria. European Journal of Operational Research, 209(2), 166-175. doi: 10.1016/j.ejor.2010.09.018

Received on $9^{\text {th }}$ July 2014, after revision, accepted for publication on $15^{\text {th }}$ December 2014. Published online on $22^{\text {nd }}$ December 2014

Mikica Drenovak is an Assistant Professor at the Faculty of Economics - University of Kragujevac, the Republic of Serbia. He obtained his PhD degree in Quantitative Finance, at the Faculty of Economics of Belgrade University, the Republic of Serbia. His research interests include financial markets, asset and risk management and portfolio optimization.

Vladimir Rankovic is an Associate Professor at the Faculty of Economics - University of Kragujevac, the Republic of Serbia. He received his PhD degree in technical sciences, at the Centre for interdisciplinary and multidisciplinary studies University of Kragujevac. His current research is focused on intelligent systems and computational methods and techniques in economics and finance. 


\title{
REBALANS PORTFOLIJA HARTIJA OD VREDNOSTI PRIMENOM MODELA MARKOWITZ-A SA KONTROLOM OBIMA REBALANSA
}

\author{
Mikica Drenovak*, Vladimir Ranković \\ Ekonomski fakultet Univerziteta u Kragujevcu
}

\begin{abstract}
Upravljanje portfolijom hartija od vrednosti podrazumeva periodični rebalans portfolija, tj. promenu strukture portfolija sa ciljem prilagođavanja okolnostima na tržištu. Svrha rebalansa jeste da se poprave performanse portfolija prema zadatom kriterijumu. Cilj ovog istraživanja je testiranje dva nova pristupa rebalansu portfolija hartija od vrednosti, jednog zasnovanog na optimalnoj vrednosti tržišnog rizika, a drugog na optimalnom odnosu rizika i prinosa. Za inicijalnu alokaciju i rebalans u radu koristimo optimalnu volatilnost ili Sharpe-ov količnik. Kako bi ponuđena rešenja bila primenljiva u praksi, uvodimo okidače za rebalans i na taj način kontrolišemo obim rebalansa portfolija i, posredno, ukupne transakcione troškove. Rezultati ukazuju na to da je strategija periodične minimizacije volatilnosti portfolija odgovarajuća alternativa za investitore netolerantne na rizik jer, uz umereni obim i nisku dinamiku rebalansa, obezbeđuje portfolio sa boljim vrednostima rizika u poređenju sa referentnim S\&P 100 tržišnim indeksom i 1/n portfolijom.
\end{abstract}

Ključne reči: upravljanje portfolijom, volatilnost, Sharpe-ov količnik, rebalans portfolija, obim rebalansa

\section{UVOD}

Upravljanje portfolijom počinje alokacijom sredstava. Postoji konsenzus da početna alokacija u značajnoj meri utiče na performanse (Arshanapalli, Coggin \& Nelson, 2001). Aktivno upravljanje portfolijom podrazumeva rebalans postojećeg portfolija kupovinom i prodajom hartija od vrednosti. Cilj rebalansa jeste da se unaprede performanse posmatranog portfolija prilagođavanjem trenutnim tržišnim uslovima i/ili očekivanjima.

\footnotetext{
* Korespondencija: M. Drenovak, Ekonomski fakultet Univerziteta u Kragujevcu, Đ. Pucara 3, 34000 Kragujevac, Srbija; e-mail: mdrenovak@kg.ac.rs
}

Međutim, rebalans portfolija izaziva troškove trgovanja (transakscione troškove), koji negativno utiču na krajnji prinos. Zbog toga se transakcioni troškovi neizostavno uzimaju u obzir prilikom razvoja dinamičkog modela upravljanja portfolijom u realnim tržišnim uslovima. (Choi, Jang \& Koo, 2007; Kozhan \& Schmid, 2009).

Decenijama unazad tržišni rizik se definiše kao varijansa (odnosno, volatilnost) prinosa portfolija. Portfolio alokacija je tradicionalno zasnovana na H. M. Markowitz-evom modelu odnosa prinosa i varijanse (mean-variance model) (Markowitz, 1952; Fabozzi, Focardi \& Jonas, 2007). U ovom radu, u okvirima 
Markowitz-evog modela, razmatramo dve različite strategije upravljanja portfolijom hartija od vrednosti. Jedna je bazirana na periodičnoj minimizaciji tržišnog rizika merenog volatilnošću prinosa (volatility), a druga na periodičnoj maksimizaciji tzv. W. F. Sharpe-ovog količnika (1966).

Rešavanje problema portfolio alokacije zasnovano je na "pomirenju” dva suprotstavljena cilja minimizacija rizika i maksimizacija prinosa. Tržišni rizik (Alexander, 2008) predstavlja rizik od nepovoljnih kretanja cena finansijskih instrumenata. Međutim, dok je regulator primarno zainteresovan za aspekt rizika portfolija hartija od vrednosti (Jaksic, 2012), investitori su prevashodno zainteresovani za prinos, pa rizik posmatraju samo u kontekstu prinosa (realizovanih ili očekivanih). Po pravilu, portfolio menadžeri u izveštajima o performansama portfolija navode vrednost realizovanog prinosa po jedinici rizika za posmatrani period. U finansijskim izveštajima standardno je navođenje Sharpe-ovog količnika, definisanog kao prinos po jedinici utvrđene volatilnosti (Bacon, 2008).

Cilj ovog istraživanja je da se utvrdi da li periodični rebalans portfolija, zasnovan na optimizaciji volatilnosti (ili alternativno Sharpe-ovog količnika), može da obezbedi bolje performanse (i u kom kontekstu bolje) upravljanog portfolija $\mathrm{u}$ odnosu na predloženi reper.

U skladu sa postavljenim ciljem istraživanja $u$ radu ćemo testirati dve hipoteze:

H1: Primenom periodične minimizacije volatilnosti dobija se portfolio sa boljim parametrima rizika $\mathrm{u}$ odnosu na izabrane repere.

H2: Primenom periodične maksimizacije Sharpeovog količnika dobija se portfolio sa većim Sharpe-ovim količnikom u odnosu na izabrane repere.

$S$ ciljem da kontrolišemo obim rebalansa, uvodimo različite okidače (uslove) za aktiviranje postupka rebalansa. U ovom istraživanju kao oportunitetni skup koristimo skup od 40 konstituenata tržišnog indeksa S\&P 100. Za period upravljanja portfolijom usvojili smo period od 2 godine. Performanse upravljanog portfolija u pogledu odnosa rizik-prinos, kao i ukupnog obima rebalansa, poredimo sa performansama indeksa S\&P
100, usvojenog da bude tržišni benčmark ${ }^{1}$, kao i sa performansama $1 / n$ portfolija koji predstavlja osnovnu („naivnu”) portfolio strategiju.

Izbor strategije rebalansa portfolija zavisi od investicionog cilja koji investitor želi da postigne (Hsu, 2012). U literaturi koja se odnosi na probleme rebalansa portfolija različiti autori su razmatrali različite strategije rebalansa i njihov uticaj na sveukupne performanse portfolija hartija od vrednosti. B. Arshanapalli i ostali (2001) analizirali su uticaj strukture alokacije sredstava na performanse portfolija sa fiksnim ponderima, kao i sa različitim dinamičkim portfolijima, sa uključivanjem transakcionih troškova. C. Donohue i K. Yip (2003) ispitivali su efekte različitih heurističkih strategija rebalansa na performanse portfolija u kontekstu rizika, prinosa, Sharpe-ovog količnika, obima rebalansa i transakcionih troškova. Rezultati pokazuju da postoji kompromis između optimalnog rebalansa i transakcionih troškova ${ }^{2}$. K. Sippel (2012) je analizirao uticaj obima rebalansa na sveukupne performanse strategije rebalansa koja za cilj ima održavanje definisanog nivoa rizika. Autor predlaže uvođenje transakcionih pragova značaja u cilju smanjenja ukupnih transakcionih troškova, što za posledicu ima povećanje krajnjih prinosa upravljanog portfolija. V. DeMiguel, G. Lorenzo i U. Raman (2009) analiziraju performanse 14 različitih tipova Markowitz-evog modela optimalnog strukturiranja portfolija. Autori su pokazali da "naivna“ 1/n strategija strukturiranja portfolija $\mathrm{u}$ proseku daje, $\mathrm{u}$ pogledu sveukupnih performansi upravljanog portfolija, bolje rezultate čak i od složenijih portfolio strategija poznatih u praksi. A. A. Gaivoronsky, S. Krylov i N. Van der Wijst (2005) analizirali su strategiju strukturiranja portfolija baziranu na replikaciji usvojenog benčmarka (benchmark tracking approach). Autori su razvili nekoliko algoritama za strukturiranje portfolija baziranih na različitim merama rizika i testirali ih na velikom broju uzoraka. Rezultati pokazuju da strategija bazirana na replikaciji benčmarka može da bude veoma efikasna strategija investiranja. J. R. Yu i W. Y. Lee (2011) su analizirali pet različitih modela rebalansa portfolija baziranih na kombinovanju različitih kriterijuma rebalansa, uključujući rizik, prinos, zabranu kratkih pozicija, asimetričnosti i spljoštenosti distribucija prinosa, kao i analizu transakcionih troškova. Autori $\mathrm{su}$ primenili fazi višekriterijumsko programiranje $\mathrm{u}$ 
cilju definisanja opšteg višekriterijumskog modela rebalansa portfolija.

Devastirajući efekti poslednje svetske ekonomske krize imaju za rezultat da su danas i investitori i regulatori zainteresovani za merenje takozvanog rizika ekstremnih kvantila. Uprkos nepovoljnim matematičkim osobinama (Artzner, Delbaen, Eber \& Heath, 1999; Szego, 2002), vrednost pod rizikom (VaR) je najčešće korišćena mera rizika ekstremnih kvantila i postala je standard regulative koja se odnosi na bankarsko poslovanje (Basel Committee on Banking Supervision, $1996^{3}$ ). Prema poslednjim međunarodnim propisima, na osnovu VaR-a investicionih portfolija banke određuje se iznos obaveznih rezervi. Iz tog razloga, mi ćemo analizirati i karakteristike upravljanih portfolija u kontekstu vrednosti pod rizikom.

Struktura rukopisa je sledeća: u drugoj sekciji, uvodimo koncepte prinosa portfolija i obima rebalansa. Definicija rizika i Sharpe-ovog količnika koje koristimo u ovom istraživanju date su u trećoj sekciji. Model optimizacije dat je u četvrtoj sekciji. U sledećoj sekciji predstavili smo strategije rebalansa. Nakon predstavljanja empirijskih rezultatia, opredeljeni su zaključci i predlozi za buduća istraživanja.

\section{MATEMATIČKA INTERPRETACIJA PRINOSA PORTFOLIJA I OBIMA REBALANSA}

U ovom poglavlju uvodimo osnovne pojmove portfolio teorije korišćene $u$ istraživanju.

Procentualni prinos portfolija za posmatrani period $u$ trenutku t definisan je sledećim izrazom:

$r_{p, t}=\sum_{i=1}^{N} w_{i, t-1} r_{i, t}$

gde $r_{i, t}$ označava prinos hartije $i \mathrm{u}$ trenutku $t$, a $w_{i, t}$ označava težinski koeficijent, odnosno, udeo kapitala investiranog $\mathrm{u}$ hartiju $i \mathrm{u}$ trenutku $t$.

Izraz (1) predstavlja fundamentalnu relaciju u portfolio matematici (Alexander, 2008).

Koeficijent $w_{i, t}$ je definisan sledećim izrazom: $w_{i, t}=\frac{n_{i} p_{i, t}}{\sum_{i=1}^{N} n_{i} p_{i, t}}, \quad i=1, \ldots, N$,

gde $n_{i}$ označava broj kupljenih hartija od vrednosti $i$, a $p_{i, t}$ cenu jedne hartije $i$ u trenutku $t$.

Broj hartija od vrednosti $n_{i}$ ostaje isti za svaku hartiju od vrednosti $i$ u periodu između dva rebalansa (tj. portfolio je statički $u$ tom periodu). $S$ druge strane, vrednost težinskog koeficijenta $w_{i, t}$ se menja u periodu između dva rebalansa svaki put kad se promeni cena bilo koje hartije portfolija. Transakcioni troškovi, koji se javljaju prilikom svakog rebalansa, mogu da imaju veliki uticaj na sveukupni prinos upravljanog portfolija. U praksi, portfolio menadžer mora da kontroliše transakcione troškove prilikom rebalansa kako ne bi narušio sveukupne performanse upravljanog portfolija. Drugim rečima, portfolio menadžer će izvršiti rebalans portfolija samo ukoliko se zahtevani transakcioni troškovi nalaze $\mathrm{u}$ prihvatljivim granicama. Zbog toga se transakcioni troškovi u teoriji upravljanja portfolijom posmatraju kao ograničenje. U opštem slučaju, transakcioni troškovi zavise od velikog broja faktora, ali je u svakom obrascu za računanje transakcionih troškova osnovna promenljiva obim trgovanja. Zbog toga, $u$ ovom istraživanju, kao približnu meru transakcionih troškova koristimo obim rebalansa portfolija. Portfolio turnover $\mathrm{u}$ trenutku $t$, definiše se kao relativni udeo $\mathrm{u}$ vrednosti portfolija i može da se izračuna po sledećem obrascu (DeMiquel et al, 2009):

Obim rebalansa $(t)=\sum_{i=1}^{N}\left|w_{i, t}-w_{i, t-1}\right|$

\section{RIZIK EKSTREMNIH KVANTILA I} SHARPE-OV KOLIČNIK

\section{Volatilnost}

Varijabilnost portfolija tradicionalno se izražava varijansom prinosa portfolija: 
$\sigma_{p}^{2}=\frac{1}{T} \sum_{t=1}^{T}\left(r_{t}-\bar{r}_{p}\right)^{2}$, gde je $r_{i}$ prinos portfolija $\mathrm{u}$

trenutku $t, \bar{r}_{p}$ prosečni prinos portfolija. Često se umesto varijanse koristi standardna devijacija prinosa, $\sigma_{p}, \mathrm{tj}$. kvadratni koren varijanse, kao mera varijabilnosti, imajući u vidu da je standardna devijacija veličina istog reda kao i prosečni prinos. U izveštajima za investitore standardna mera varijabilnosti portfolija je volatilnost, koja se računa kao anualizovana standardna devijacija prinosa:

volatilnost $=\sigma_{p} \sqrt{252}$

\section{Sharpe-ov količnik}

Sharpe-ov količnik ${ }^{5}$ meri prinos portfolija po jedinici rizika. Ovo je jedna od najčešće korišćenih mera performansi portfolija koja objedinjuje prinos i rizik (risk-adjusted return). U praksi, prinos se obično računa relativno $\mathrm{u}$ odnosu na bezrizičnu kamatnu stopu dok se rizik, izvorno, meri standardnom devijacijom prinosa portfolija $\mathrm{u}$ posmatranom periodu, pa se, $\mathrm{u}$ skladu sa tim, Sharpe-ov količnik može formalno definisati kao:

Sharpe $=\frac{\bar{r}_{p}-r_{f}}{\sigma_{p}}$,

gde je $\bar{r}_{p}$ stopa prosečnog (realizovanog ili očekivanog $\mathrm{u}$ zavisnosti od toga da li je vrednost računata u ex post ili ex ante kontekstu) prinosa portfolija, $r_{f}$ bezrizična kamatna stopa, a $\sigma_{p}$ standardna devijacija portfolija $\mathrm{u}$ posmatranom periodu. Na osnovu izraza (5) jasno je da će, od dva portfolija sa jednakim stopama prinosa, veću vrednost Sharpe-ovog količnika imati onaj portfolio sa manjom standardnom devijacijom stope prinosa. Sharpe-ov količnik je u praksi standardna mera za ocenu performansi portfolija, jer omogućava poređenje dva portfolija koji imaju različite prosečne prinose i vrednosti rizika.

\section{OPTIMIZACIONI MODEL}

U ovom radu analiziramo dve različite strategije upravljanja portfolijom zasnovane na: a) minimizaciji volatilnosti portfolija, i b) maksimizaciji Sharpe-ovog količnika portfolija. Opšta forma optimizacionog modela je:

a) min volatilnost $\left(r_{p}(\boldsymbol{w})\right)$

b) max Sharpe $\left(r_{p}(\boldsymbol{w})\right)$

$\sum_{i=1}^{N} w_{i}=1$

$0 \leqslant w_{i} \leqslant 1, i=1, \ldots, N$

pri čemu $w$ označava vektor težinskih koeficijenata $w_{i}$, volatilnost $\left(r_{p}(\mathbf{w})\right)$ označava volatilnost portfolija, Sharpe $\left(r_{p}(\mathbf{w})\right)$ označava Sharpe-ov količnik, a N ukupan broj hartija od vrednosti.

Jednačina (6) definiše kriterijume optimizacije, jednačina (7) predstavlja standardno ograničenje budžeta koje nameće da je zbir svih težinskih koeficijenata jednak 1. Jednačina (8) nameće ograničenje da težinski koeficijenti moraju da budu pozitivni, što u praksi znači da nije dozvoljeno zauzimanje kratkih pozicija.

Treba naglasiti da su vrednosti kriterijuma optimizacije (Volatilnost i Sharpe-ov količnik) računati na osnovu vremenske serije realizovanih prinosa portfolija. Da bi se odredila vremenska serija realizovanih prinosa potencijalnog portfolija, neophodno je dnevno preračunavanje težinskih koeficijenata $w_{i, t}$.

\section{STRATEGIJE REBALANSA}

Strategije rebalansa koje su razmatrane $u$ ovom radu su bazirane na dnevnoj optimizaciji portfolija po usvojenom kriterijumu optimizacije (jednačina (6)).

$\mathrm{Na}$ početku perioda upravljanja portfolijom neophodno je usvojiti inicijalni portfolio. U ovom radu smo usvojili da inicijalni portfolio bude portfolio koji je optimizovan po predloženom kriterijumu optimizacije, tj. $u$ slučaju strategije bazirane na minimizaciji volatilnosti inicijalni portfolio je portfolio koji ima minimalnu volatilnost, a u slučaju strategije koja se bazira na maksimizaciji Sharpe-ovog količnika inicijalni portfolio je portfolio sa najvećom vrednošću Sharpe-ovog količnika. Inicijalni portfolio je definisan 
vektorom težinskih koeficijenata $w$. Međutim, aktuelni portfolio je definisan brojem kupljenih hartija svake od hartija od vrednosti iz oportunitetnog skupa. Zbog toga je neophodno prevođenje težinskih koeficijenata u broj odgovarajućih hartija od vrednosti. Da bi to bilo moguće, pretpostavili smo da je inicijalna vrednost portfolija 1 milion novčanih jedinica.

Ovde predloženo upravljanje portfolijom se sastoji u sledećem: Svakog dana u okviru usvojenog perioda upravljanja portfolijom sprovodimo optimizaciju portfolija. Na taj način svakog dana imamo na raspolaganju dva portfolija, tekući i potencijalni koji je dobijen postupkom optimizacije po predloženom kriterijumu. Ukoliko je zadovoljen uslov rebalansa (okidač se aktivira), vršimo rebalans, čime potencijalni portfolio postaje tekući. U suprotnom, zadržavamo tekući portfolio. Treba naglasiti da potencijalni portfolio dobijen optimizacijom po određenom kriterijumu može da poseduje neznatno bolju vrednost kriterijuma optimizacije u odnosu na tekući portfolio. Zbog toga smo usvojili da se rebalans izvršava samo ukoliko je vrednost kriterijuma optimizovanog portfolija dovoljno bolja od vrednosti kriterijuma optimizacije tekućeg portfolija. Minimalno poboljšanje u radu je postavljeno na $1 \%$.

\section{PODACI I REZULTATI ISTRAŽIVANJA}

U ovoj sekciji rada predstavljamo rezultate empirijskog istraživanja dobijene primenom predloženih strategija rebalansa. Svi numerički eksperimenti su izvršeni na istorijskim podacima. Za ovo istraživanje smo koristili 40 konstituenata indeksa S\&P 100 (Tiker: OEX) koji su imali najveću vrednost tržišne kapitalizacije 6 . septembra $2013^{6}$.

Upravljanje portfolijom primenom predloženih strategija rebalansa sprovedeno je $u$ periodu od 2 godine (504 radna dana), počevši od 2. januara 2009. zaključno sa 31. decembrom 2010. Za ocenu volatilnosti i Sharpe-ovog količnika koristili smo vremenske serije od po 500 dnevnih prinosa portfolija.

U cilju analize portfolija dobijenih primenom predloženih strategija rebalansa, njihove performanse smo poredili sa performansama naivnog $1 / n$ portfolija, kao i sa performansama referentnog indeksa S\&P 100.

Na Slici 1 predstavljena je evolucija tržišne vrednosti portfolija dobijenih primenom strategije minimizacije volatilnosti (označene sa Min Vol), strategije maksimizacije Sharpe-ovog količnika portfolija

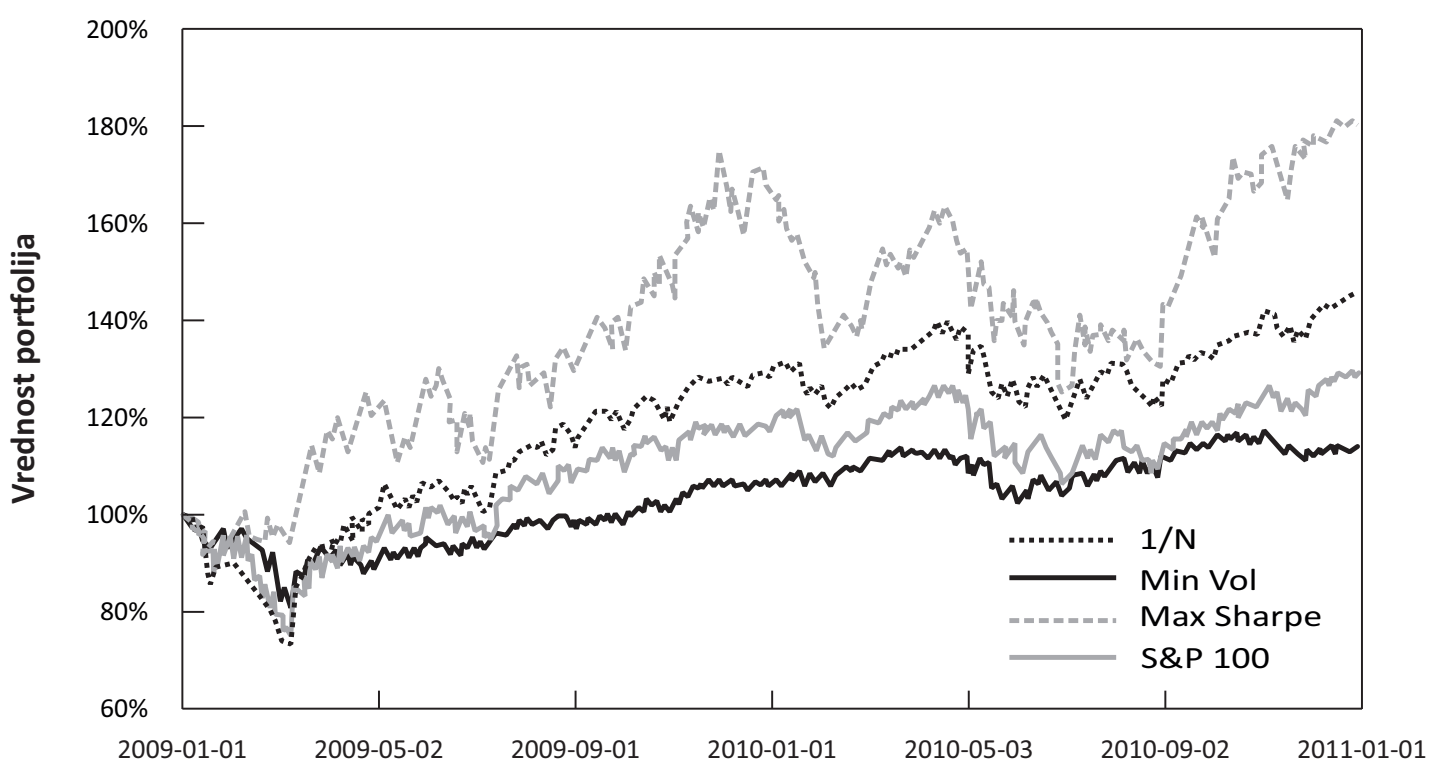

Slika 1 Tržišna vrednost portfolija upravljanih Min Vol, Max Sharpe, naivnog 1/n portfolija i referentni S\&P 100 indeks u periodu 2. januar 2009 - 31. decembar 2010. 
(označene sa Max Sharpe), kao i 1/n portfolija zajedno sa tržišnom vrednošću indeksa S\&P100. Vrednosti su početno normalizovane na 100.

Za finansijske institucije na koje se primenjuje Bazel regulativa vrednosti ocena $1 \% \mathrm{VaR}$-a će uticati na nivo kapitalnih rezervi. Na Slici 2 predstavljamo evoluciju ocena $1 \% \mathrm{VaR}-\mathrm{a}$ u posmatranom periodu za Min Vol, Max Sharpe, 1/n portfolije, kao i za indeks S\&P100.

U Tabeli 1 predstavljamo statističku analizu performansi upravljanih portfolija.

Očekivano, strategija rebalansa bazirana na minimizaciji volatilnosti obezbeđuje najniže vrednosti volatilnosti i, dodatno, najniže vrednosti ocena $1 \%$ VaR-a u periodu upravljanja portfolija. S druge strane, strategija rebalansa koja je bazirana na maksimizaciji Sharpe-ovog količnika daje portfolio sa najvećim Sharpe-količnikom, ali najvišom ocenom VaR-a i najvećom volatilnošću u posmatranom periodu. Visoka volatilnost može da bude posledica izrazitih promena u strukturi portfolija (Tabela 1). Vremenske serije ocena VaR-a, takođe, otkrivaju velike promene $\mathrm{u}$ strukturi Max Sharpe portfolija.

Rezultati u Tabeli 1 pokazuju da strategija rebalansa koja se bazira na maksimizaciji Sharpe-ovog količnika obezbeđuje najveće vrednosti prinosa (ukupnog i prosečnog), kao i najveću vrednost Sharpe-ovog količnika, ali uz istovemenu najveću vrednost obima rebalansa (36 puta veću od prosečne vrednosti portfolija). S druge strane, strategija bazirana na minimizaciji volatilnosti obezbeđuje najmanju vrednost volatilnosti i VaR-a. Međutim, ova strategija se odlikuje i najnižim vrednostima prinosa. U poređenju sa performansama referentnog indeksa S\&P 100, Min Vol strategija pruža nižu vrednost prinosa, ali i značajno nižu vrednost volatilnosti i VaR-a (isto važi i ako se poređenje vrši sa $1 / n$ strategijom). Dodatno, VaR ocene su najniže kod Min Vol, a najviše kod Max Sharpe strategije, što ukazuje na razlike u efikasnosti upotrebe kapitalnih rezervi. Drugi benčmark $u$ ovom istraživanju, naivna $1 / n$ strategija odlikuje se performansama koje su po vrednostima pokazatelja prinosa i rizika između Min Vol i Max Sharpe

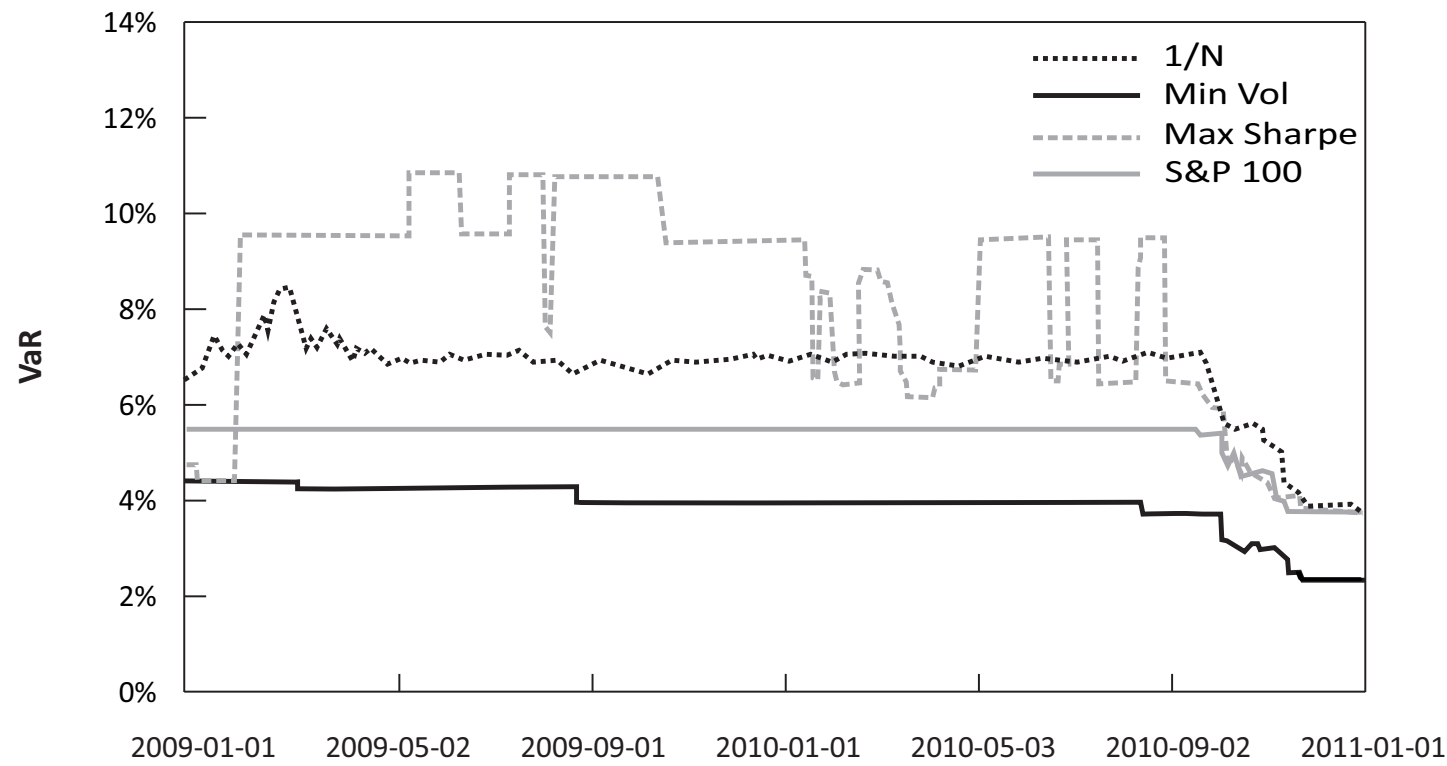

Slika 2 Evolucija ocena 1\%VaR-a portfolija za Min Vol, Max Sharpe, naivni 1/n portfolio i referentni S\&P 100 indeks u periodu 2. januar 2009 - 31. decembar 2010. 
Tabela 1 Statistička analiza performansi Min Vol, Max Sharpe, naivnog 1/n portfolija i referentnog S\&P 100 indeksa u periodu 2. januar 2009 - 31. decembar 2010.

\begin{tabular}{l|cccc}
\hline & Min Vol & Max Sharpe & $1 / \mathrm{N}$ & S\&P 100 \\
\hline Ukupni prinos & $11.18 \%$ & $79.12 \%$ & $43.68 \%$ & $27.31 \%$ \\
Ukupni obim rebalansa & $204.06 \%$ & $3658.67 \%$ & $569.25 \%$ & - \\
Broj rebalansa & 7 & 46 & 504 & - \\
Prosečni godišnji prinos & $6.31 \%$ & $34.48 \%$ & $21.11 \%$ & $14.45 \%$ \\
Volatilnost & $14.18 \%$ & $32.56 \%$ & $24.35 \%$ & $21.70 \%$ \\
1\%VaR & $2.77 \%$ & $4.65 \%$ & $4.62 \%$ & $4.05 \%$ \\
Maksimalni gubitak* & $-8.03 \%$ & $-8.97 \%$ & $-8.56 \%$ & $-7.84 \%$ \\
Sharpe-ov količnik** & 0.42 & 1.05 & 0.86 & 0.65 \\
Prosečan broj hartija od vrednosti & 7.2 & 1.6 & 40 & 100 \\
\hline
\end{tabular}

* Maksimalni gubitak (max drawdawn) se računa kao maksimalni trodnevni gubitak. Period od tri dana je uzet na osnovu pretpostavke da je to period dovoljan da se izađe iz određene pozicije na likvidnim tržištima.

** Prilikom računanja Sharpe-ovog količnika za vrednost bezrizične kamatne stope usvojena je stopa na jednogodišnje zapise USA trezora, čija je vrednost na dan 31. Decembar 2010 iznosila 0.29\% (U.S. Department of the Treasury)

Izvor: Autori

strategije, što se moglo i očekivati od strategije koja se bazira na naivnoj diversifikaciji (Arshanapalli et al, 2001).

Treba naglasiti da, iako je frekvencija rebalansa Max Sharpe strategije prihvatljiva, $u$ realnim tržišnim uslovima vrednost obima rebalansa pojedinačnih rebalansa je u većini slučajeva neprihvatljivo visoka. $S$ druge strane, naivna $1 / \mathrm{n}$ strategija podrazumeva dnevni rebalans portfolija $u$ cilju zadržavanja podjednakog učešća svih hartija od vrednosti u ukupnoj vrednosti portfolija. Stoga je opšti zaključak da su i za Max Sharpe i 1/n strategiju ukupne vrednosti obima rebalansa veoma visoke, što za posledicu ima visoke vrednosti transakcionih troškova, pa su kao takve neprihvatljive u realnim tržišnim uslovima.

U cilju smanjenja ukupnog obima rebalansa, uvodimo dodatna ograničenja za izvršavanja rebalansa.

U slučaju Min Vol i Max Sharpe strategija, rebalans se izvršava samo ukoliko je rezultujući obim rebalansa manji od $50 \%$ od ukupne vrednosti portfolija. U slučaju naivne $1 / \mathrm{n}$ strategije, rebalans se izvršava samo ukoliko je rezultujući obim veći od 5\% od ukupne vrednosti portfolija. U suprotnom, zadržava se tekući portfolio.

Na Slici 3 predstavljena je evolucija tržišne vrednosti portfolija dobijenih primenom Min Vol, Max Sharpe i $1 / n$ portfolio strategije i novouvedenih ograničenja. Na Slici 4 predstavljena je evolucija ocena 1\%VaR-a za iste portfolije. Na obe slike ponovo smo prikazali i odgovarajuće vrednosti referentnog indeksa S\&P 100.

U Tabeli 2 predstavljamo statističku analizu performansi analiziranih portfolija sa dodatnim ograničenjima u pogledu vrednosti obima rebalansa.

Nakon uvođenja predloženih ograničenja Min Vol portfolio ostao je isti, dok se ukupni obim rebalansa Max Sharpe portfolija smanjio na $13.73 \%$ sa svega 3 realizacije rebalansa. Međutim, sada Max Sharpe strategija ima najniži prosečan prinos $(14.08 \%)$ sa padom većim od $50 \%$ u pogledu ukupnog prinosa $u$ poređenju sa verzijom ove strategije bez ograničenja. Štaviše, Sharpe-ov količnik više nije najveći $u$ posmatranom skupu strategija. 


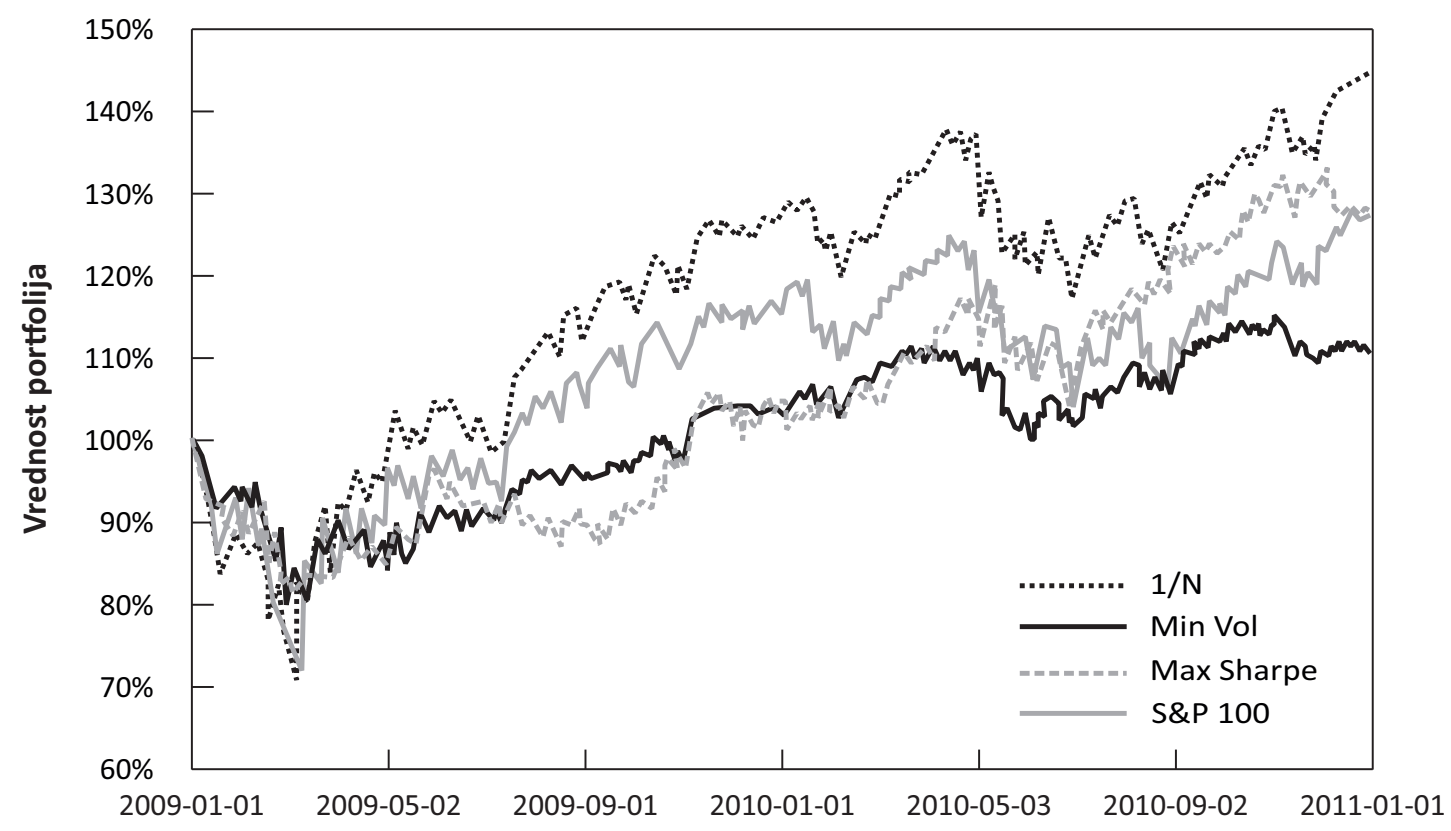

Slika 3 Tržišna vrednost Min Vol i Max Sharpe portfolija sa uvedenim ograničenjem maksimalnog dozvoljenog obima rebalansa, naivnog $1 / n$ portfolija sa uvedenim ograničenjem minimalnog obima rebalansa, i referentnog S\&P 100 indeksa u periodu 2. januar 2009 - 31. decembar 2010.

Izvor: Autori

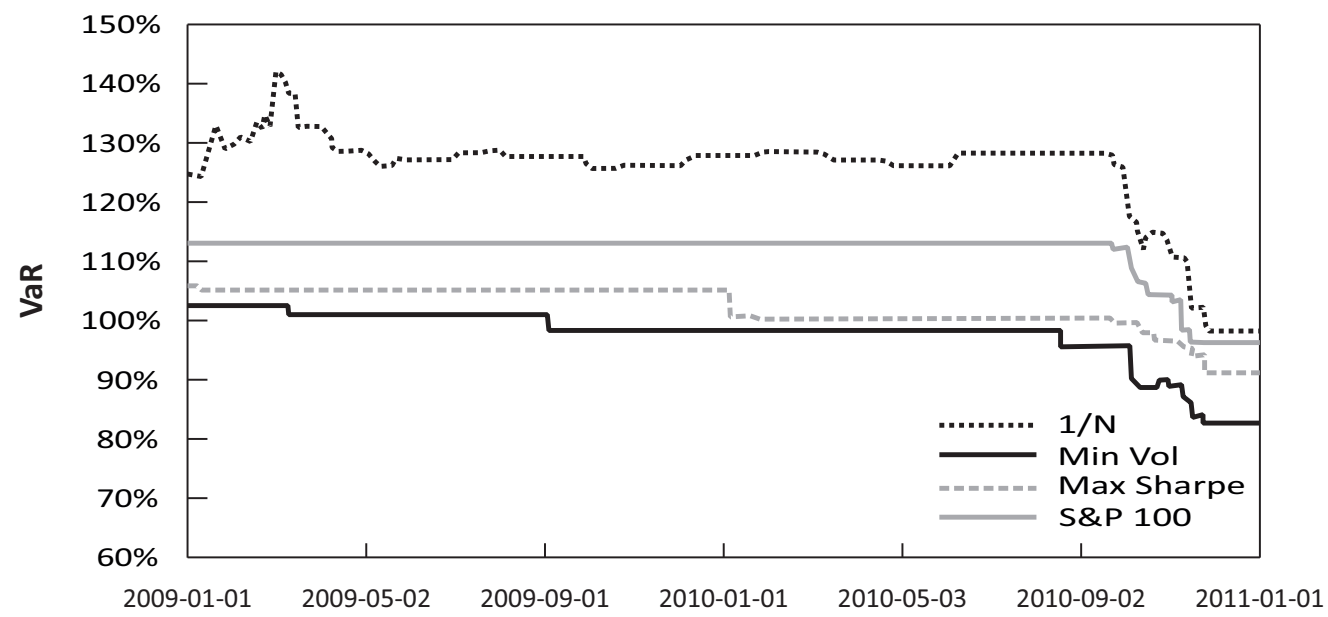

Slika 4 Evolucija ocena 1\%VaR-a Min Vol i Max Sharpe portfolija sa uvedenim ograničenjem maksimalnog dozvoljenog obima rebalansa, naivnog $1 / \mathrm{n}$ portfolija sa uvedenim ograničenjem minimalnog obima rebalansa, $\mathrm{i}$ referentnog S\&P 100 indeksa u periodu 2. januar 2009 - 31. decembar 2010. 
Tabela 2 Statistička analiza performansi Min Vol i Max Sharpe portfolija sa uvedenim ograničenjem maksimalnog dozvoljenog obima rebalansa, naivnog $1 / \mathrm{n}$ portfolija sa uvedenim ograničenjem minimalnog obima rebalansa i referentnog S\&P 100 indeksa u periodu 2. januar 2009 - 31. decembar 2010.

\begin{tabular}{|c|c|c|c|c|}
\hline & $\begin{array}{c}\text { Min Vol } \\
\text { Obim reb. }<50 \%\end{array}$ & $\begin{array}{c}\text { Max Sharpe } \\
\text { Obim reb. }<50 \%\end{array}$ & $\begin{array}{c}1 / \mathrm{N} \\
\text { Obim reb.>5\% }\end{array}$ & S\&P 100 \\
\hline Ukupni prinos & $11.18 \%$ & $27.72 \%$ & $43.76 \%$ & $27 \cdot 31 \%$ \\
\hline Ukupni obim rebalansa & $204.06 \%$ & $13.73 \%$ & $158.48 \%$ & - \\
\hline Broj rebalansa & 7 & 3 & 29 & - \\
\hline Prosečni godišnji prinos & $6.31 \%$ & $14.08 \%$ & $21.14 \%$ & $14.45 \%$ \\
\hline Volatilnost & $14.18 \%$ & $19.09 \%$ & $24.36 \%$ & $21.70 \%$ \\
\hline $1 \% \mathrm{VaR}$ & $2.77 \%$ & $3.05 \%$ & $4.45 \%$ & $4.05 \%$ \\
\hline Maksimalni gubitak* & $-8.03 \%$ & $-4.89 \%$ & $-8.23 \%$ & $-7.84 \%$ \\
\hline Sharpe-ov količnik** & 0.42 & 0.72 & 0.86 & 0.65 \\
\hline Prosečan broj hartija od vrednosti & 7.2 & 2.0 & 40 & 100 \\
\hline
\end{tabular}

* Maksimalni gubitak (max drawdawn) se računa kao maksimalni trodnevni gubitak. Period od tri dana je uzet na osnovu pretpostavke da je to period dovoljan da se izađe iz određene pozicije na likvidnim tržištima.

** Prilikom računanja Sharpe-ovog količnika za vrednost bezrizične kamatne stope usvojena je stopa na jednogodišnje zapise USA trezora, čija je vrednost na dan 31. Decembar 2010 iznosila 0.29\% (U.S. Department of the Treasury)

Izvor: Autori

Min Vol strategija obezbeđuje, ponovo, najnižu vrednost volatilnosti i $1 \% V a R-a$ portfolija.

Uvođenje ograničenja minimalnog dozvoljenog obima rebalansa u naivnu $1 / \mathrm{n}$ strategiju imalo je za posledicu značajno niži ukupni obima rebalansa $(158.48 \%$ naspram 569.25\%) sa svega 29 umesto 504 izvršena rebalansa. Istovremeno, sveukupne performanse $1 / n$ portfolija su vrlo malo promenjene.

Cilj portfolio alokacije je da se postigne efekat diversifikacije, tj. da se eliminiše specifičan rizik pojedinačnih hartija od vrednosti, a da se istovremeno postignu bolje rizik-prinos karakteristike. Prema portfolio teoriji, više hartija u portfoliju obezbeđuje bolji efekat diversifikacije (Markowitz, 1952). U praksi se, međutim, investitori trude da postignu što bolje efekte diversifikacije sa ograničenim brojem hartija, jer na taj način izbegavaju velike transakcione troškove. Strategije koje su predstavljene $\mathrm{u}$ ovom radu testirane su na oportunitetnom skupu od 40 hartija ${ }^{7}$. U pogledu diversifikacije, Max Sharpe strategija sa svega 2 hartije u proseku obezbeđuje skromne efekte diversifikacije bez obzira na to da li je ograničenje maksimalnog dozvoljenog obima rebalansa uključeno ili ne. $S$ druge strane, Min Vol strategija sa 7 hartija u proseku daje bolje parametre rizika (u pogledu volatilnosti i VaR-a) u odnosu na $1 / n$ strategiju i referentni indeks S\&P 100, na račun prinosa.

Sa ciljem da proverimo robusnost rezultata ispitali smo iste strategije primenjujući ih na novi period od 2 godine (504 dana) od 1. septembra 2011. do 4 . septembra 2013. godine. U Tabeli 3 predstavljamo statističku analizu performansi Min Vol i Max Sharpe portfolija sa uvedenim ograničenjem maksimalnog dozvoljenog obima rebalansa, naivnog $1 / n$ portfolija sa uvedenim ograničenjem minimalnog obima rebalansa i referentnog S\&P 100 indeksa za novoposmatrani period (S\&P 100 index, https://finance.yahoo.com). Dobijeni rezultati su konzistentni sa rezultatima dobijenim za prethodno analizirani period (osim što sada Max Sharpe strategiju karakaterišu veći broj rebalansa i veći obim rebalansa). Da bi rezultati bili u 
Tabela 3 Statistička analiza performansi Min Vol i Max Sharpe portfolija sa uvedenim ograničenjem maksimalnog dozvoljenog obima rebalansa, naivnog $1 / \mathrm{n}$ portfolija sa uvedenim ograničenjem minimalnog obima rebalansa i referentnog S\&P 100 indeksa u periodu 1. septembar 2011-4. septembar 2013.

\begin{tabular}{l|cccc}
\hline & $\begin{array}{c}\text { Min Vol } \\
\text { Obim reb.<50\% }\end{array}$ & $\begin{array}{c}\text { Max Sharpe } \\
\text { Obim reb. }<50 \%\end{array}$ & $\begin{array}{c}1 / \mathrm{N} \\
\text { Obim reb.>5\% }\end{array}$ & S\&P 100 \\
\hline Ukupni prinos & $23.54 \%$ & $35.05 \%$ & $43.92 \%$ & $36.33 \%$ \\
Ukupni obim rebalansa & $82.15 \%$ & $273.03 \%$ & $67.19 \%$ & \\
Broj rebalansa & 5 & 9 & 14 & \\
Prosečni godišnji prinos & $11.14 \%$ & $16.15 \%$ & $19.39 \%$ & $16.69 \%$ \\
Volatilnost & $10.45 \%$ & $14.82 \%$ & $15.15 \%$ & $15.24 \%$ \\
1\%VaR & $1.87 \%$ & $2.37 \%$ & $2.60 \%$ & $2.59 \%$ \\
Maksimalni gubitak* & $-3.70 \%$ & $-4.89 \%$ & $-8.23 \%$ & $-5.89 \%$ \\
Sharpe-ov količnik** & 1.04 & 1.07 & 1.26 & 1.07 \\
Prosečan broj hartija od vrednosti & 5.4 & 3.4 & 40 & 100 \\
\hline
\end{tabular}

* Maksimalni gubitak (max drawdawn) se računa kao maksimalni trodnevni gubitak. Period od tri dana je uzet na osnovu pretpostavke da je to period dovoljan da se izađe iz određene pozicije na likvidnim tržištima.

** Prilikom računanja Sharpe-ovog količnika za vrednost bezrizične kamatne stope usvojena je stopa na jednogodišnje zapise USA trezora, čija je vrednost na dan 31. Decembar 2010 iznosila 0.29\% (U.S. Department of the Treasury)

Izvor: Autori

potpunosti uporedivi, koristimo istu kamatnu stopu na jednogodišnje zapise američkog trezora od $0.29 \%$.

\section{ZAKLJUČAK}

$\mathrm{U}$ ovom radu predstavljene su dve strategije upravljanja portfolijom, jedna bazirana na minimizaciji volatilnosti, i druga koja je bazirana na maksimizaciji Sharpe-ovog količnika. Performanse predloženih strategija su poređene sa dva referentna portfolija, jedan je tržišni portfolio predstavljen indeksom S\&P 100 , a drugi je dobijen primenom $1 / n$ strategije.

Konzistentno sa hipotezom H1, rezultati pokazuju da Min Vol strategija daje portfolio sa minimalnim rizikom (merenim volatilnošću i $1 \%$ VaR-om). Max Sharpe strategija rezultuje portfolijom sa maksimalnim prinosom (apsolutnim prinosom i prinosom po jedinici rizika merenog Sharpe-ovim količnikom), što je u skladu sa hipotezom H2. Iako su u teorijskom smislu rešenja privlačna, $u$ realnim tržišnim uslovima dobijena rešenja nisu prihvatljiva s obzirom na vrlo visoke vrednosti obima rebalansa ${ }^{8}$. U cilju smanjenja i kontrole obima rebalansa uveli smo ograničenja maksimalno dozvoljenog obima.

Primena ograničenja obima rebalansa u Max Sharpe strategiji je rezultirala značajnim smanjenjem ukupnog obima rebalansa, ali je za posledicu imala drastično pogoršanje performansi. Međutim, primena istog ograničenja u Min Vol strategiji nije uticala na krajnji portfolio, dok su performanse $\mathrm{u}$ pogledu rizika ostale superiorne $u$ odnosu na referentni S\&P 100 indeks i $1 / n$ portfolio. Na osnovu svega navedenog može se zaključiti da Min Vol strategija predstavlja prihvatljivu i pogodnu alternativu strategijama zasnovanim na tržišnoj kapitalizaciji ili jednakim ponderima.

Efikasno upravljanje portfolijom hartija od vrednosti je veoma aktuelno kako $u$ naučnim finansijskim krugovima, tako i u praksi. Budući pravci istraživanja bi mogli biti usmereni ka uvođenju različitih modela transakcionih troškova i analizi uticaja različitih kriterijuma rebalansa, kao i različitih dužina vremenskih serija na osnovu kojih se dobijaju estimacije. U ovom radu mi smo primenili dva ekstremna pristupa u kontroli obima rebalansa, prvi, koji je podrazumevao samo praćenje bez kontrole 
rebalansa, i drugi, koji je podrazumevao da je rebalans dozvoljen samo ukoliko je vrednost obima rebalansa manja od neke unapred definisane. Matematički gledano, efekat uvedenog ograničenja je smanjenje prostora mogućih rešenja. Buduće istraživanje bi moglo da bude usmereno ka unapređenju postupka optimizacije na način da se uvede maksimalni dozvoljeni obim rebalansa po transakciji.

\section{ZAHVALNICA}

Ovaj rad je deo projekata osnovnih istraživanja (br. $\mathrm{OH}$ 179005 i III-44010), koje finansira Ministarstvo prosvete, nauke i tehnološkog razvoja Republike Srbije.

\section{ENDNOTE}

1 Poslednjih par godina tržišni indeksi postaju investibilni, jer se pojavljuje sve veći broj indeksnih fondova. Videti, na primer, brošuru za fond iShares S\&P 100 ETF (Tiker: OEF).

2 Optimalna strategija rebalansa je ona koja minimizira očekivane transakcione troškove i grešku replikacije.

3 Bazelske odredbe iz 1988 prvi put definišu kapitalnu adekvatnost zasnovanu na riziku.

4 Mi uzimamo da je broj radnih dana u toku jedne godine 252, s tim da je česta alternativa 250.

5 Sharpe-ov količnik je inicijalno predstavljen kao ,nagrada za varijabilnost" (Sharpe, 1966; Bacon, 2008).

6 Uvrstili smo prvih 40 konstituenata baznog indeksa S\&P 100 za koje su vrednosti dostupne na dan 3. decembar 2007.

7 Ovih 40 hartija čine više od 70\% tržišne kapitalizacije baznog S\&P 100 indeksa.

8 Rezultati koje nismo predstavili pokazuju da Max Sharpe strategija dovodi do povremenih velikih promena u sastavu portfolija.

\section{REFERENCE}

Alexander, C. (2008). Quantitative Methods in Finance. London, UK: John Wiley \& Sons Ltd.
Arshanapalli, B., Coggin, T. D., \& Nelson. W. (2001). Is FixedWeight Asset Allocation Really Better? The Journal of Portfolio Management, 27(4), 27-38. doi: 10.3905/jpm.2001.319799

Artzner, P., Delbaen, F., Eber, J. M., \& Heath, D. (1999). Coherent measures of risk. Mathematical Finance, 9(3), 203-228. doi: $10.1111 / 1467-9965.00068$

Bacon, C. (2008), Practical portfolio performance measurement and attribution. London, UK: John Wiley \& Sons.

Basel Committee on Banking Supervision, (1996). Amendment to the Capital Accord to Incorporate Market Risks. Bank for International Settlements.

Choi, U. J., Jang, B. G., \& Koo, H. K. (2007). An algorithm for optimal portfolio selection problems with transaction costs and random lifetimes. Applied Mathematics and Computation. 191, 239-252. doi: 10.1016/j.amc.2007.02.100

Donohue, C., \& Yip, K. (2003). Optimal Portfolio Rebalancing with Transaction Costs. Journal of Portfolio Management, 29, 49-63. doi: 10.3905/jpm.2003.319894

DeMiguel, V., Lorenzo, G., \& Raman, U. (2009). Optimal Versus Naive Diversification: How Inefficient is the 1/N Portfolio Strategy? The Review of Financial Studies, 22(5), 1915-1953. doi: 10.1093/rfs/hhm075

Fabozzi F. J., Focardi, S, \& Jonas, C. (2007). Trends in quantitative equity management: Survey results. Quantitative Finance, 7, 115-122. doi: 10.1080/14697680701195941

Factsheet for the iShares S\&P 100 ETF, učitano 8. jula 2014. godine sa http://www.ishares.com/us/library?materialType $=$ Prospectus\&keyword=US4642871010.

Gaivoronski, A. A., Krylov, S., \& Van der Wijst, N. (2005). Optimal portfolio selection and dynamic benchmark tracking. European Journal of Operational Research, 163(1), 115161. doi: 10.1016/j.ejor.2003.12.001

Hsu, J. (2012). Why We Don't Rebalance. Učitano 8. jula 2014. godine sa http://www.etf.com/sections/research/12647-whywe-dont-rebalance.html?showall=\&fullart=1\&start=4

Istorijske cene S\&P 100 indeksa i njegovih konstituenata učitane na dan 8. septembar 2013 https:/finance.yahoo.com/

Jaksic, M. (2012). Risk management of portfolio securities. Ekonomic horizons, 14(3), 155-168. doi: 10.5937/ekonhor1203151J

Kozhan, R., \& Schmid, W. (2009). Asset allocation with distorted beliefs and transaction costs. European Journal of Operational Research, 194(1), 236-249. doi: 10.1016/j.ejor.2007.12.002

Markowitz, H. M. (1952). Portfolio selection. Journal of Finance, 7, 77-91. doi: 10.1111/j.1540-6261.1952.tb01525.x 
Sharpe, W. F. (1966). Mutual Fund Performance. The Journal of Business, 39(1), 119-138.

Sippel, K. (2012). Trading Costs and Index Design. Journal of Indexes Europe, September/October, 8-13, učitano 8. jula 2014. godine sa http://europe.etf.com/europe/publications/ journal-of-indexes/articles/8467-trading-costs-and-indexdesign.html
Szego, G. (2002). Measures of risk. Journal of Banking \& Finance, 26, 1253-1272. doi: 10.1016/S0378-4266(02)00262-5

U.S. Department of the Treasury, http://www.treasury.gov/ Pages/default.aspx

Yu, J. R., \& Lee, W. Y. (2011). Portfolio rebalancing model using multiple criteria. European Journal of Operational Research, 209 (2), 166-175. doi: 10.1016/j.ejor.2010.09.018

Primljeno 9. jula 2014, nakon revizije, prihvaćeno za publikovanje 15. decembra 2014. Elektronska verzija objavljena 22. decembra 2014.

Mikica Drenovak je docent na Ekonomskom fakultetu Univerziteta u Kragujevcu. Doktorirao je na Ekonomskom fakultetu Univerziteta u Beogradu, u oblasti kvantitativnih finansija. Ključne oblasti njegovog istraživačkog interesovanja su finansijska tržišta, upravljanje rizikom i optimizacija portfolija.

Vladimir Ranković je vanredni profesor na Ekonomskom fakultetu Univerziteta u Kragujevcu. Doktorat tehničkih nauka stekao je u Centru za interdisciplinarne i multidisciplinarne studije i istraživanja Univerziteta u Kragujevcu. Osnovne oblasti njegovog istraživačkog interesovanja su razvoj inteligentnih sistema i računskih metoda i tehnika, i njihova primena u ekonomiji. 


\title{
MARKOWITZ PORTFOLIO REBALANCING WITH TURNOVER MONITORING
}

\author{
Mikica Drenovak, Vladimir Rankovic \\ Faculty of Economics, University of Kragujevac, Kragujevac, Serbia
}

\begin{abstract}
Active portfolio management implies periodic rebalancing, i.e. a change in the structure of the existing portfolio. Rebalancing is aimed at improving the performance of the managed portfolio by adjusting it with respect to the given objective. The main objective of this research is to test two portfolio rebalancing strategies, one based on market risk and another on optimal risk-return tradeoff. We use optimal volatility or Sharpe of portfolio as a criterion for the initial portfolio allocation and rebalancing over the observed period. In order to obtain solutions that can be applied in practice, we impose rebalance triggers designed to control the portfolio turnover and corresponding transaction costs. the results suggest that the minimum volatility strategy can be accepted as an eligible investment alternative for risk adverse investors since it provides superior risk performance compared to the reference S\&P 100 index and 1/n portfolio, with a relatively low level of turnover and a low rebalance frequency.
\end{abstract}

Keywords: portfolio management, volatility, Sharpe ratio, portfolio rebalancing, turnover

JEL Classification: C44, C61, C11 